\title{
THE FEASIBILITY OF ASSOCIATE EU CITIZENSHIP FOR UK CITIZENS POST-BREXIT
}

\author{
A study for Jill Evans MEP \\ by
}

Prof Volker Roeben, Prof Jukka Snell, Dr Petra Minnerop, Dr Pedro Telles and Mr Keith Bush QC

Swansea University

July 2017

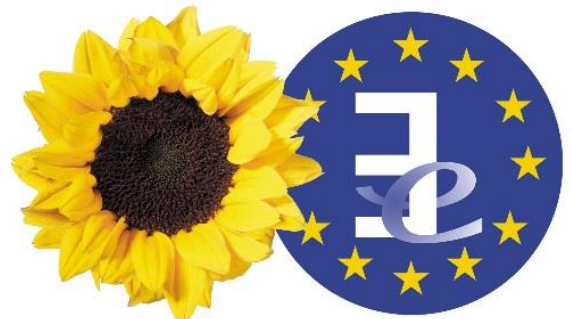

The Greens | EFA in the European Parliament

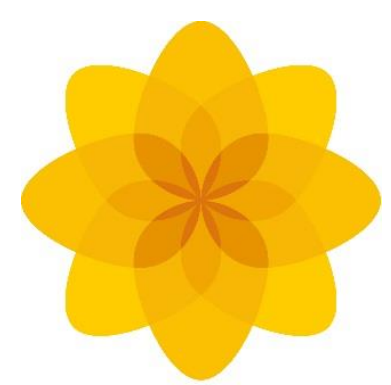

Plaid Cymru Party of Wales 
This report was commissioned by Jill Evans MEP, with the following objectives:

- Examine how realistic the idea of Associate Union Citizenship is, and how it could be developed giving all UK citizens the opportunity to retain aspects of EU citizenship;

- Set out what treaty change(s) may be necessary to develop Associate Union Citizenship;

- Considering that all 27 Member State governments and parliaments of the EU would have to agree to a treaty change, examine what could incentivise the EU-27 to agree to such a treaty change, taking account of reciprocity;

- Examine what options there could be to paid membership to access, if any;

- Consider what rights concomitant with Associate Union Citizenship are enshrined in the Government of Wales Acts and other UK legislation devolving competences to the Welsh Government and National Assembly for Wales which could strengthen the case for Associate Union Citizenship. 


\section{Foreword by Jill Evans, Plaid Cymru Member of the European Parliament for Wales}

The concept of European citizenship introduced in the 1992 Maastricht Treaty affords rights, freedoms, and legal protections to all citizens, as well as giving a legal basis to European identity. Many people in Wales passionately feel both Welsh and European, and do not want to lose their European citizenship when the UK leaves the EU.

This is the view of many hundreds of constituents who have contacted me over the past twelve months, deeply concerned at the thought of losing their European citizenship. They asked me, as their MEP, whether an 'associate citizenship' would actually be feasible.

My first step was to commission a detailed, expert opinion on the legal and constitutional options. I am extremely grateful to Professor Volker Roeben and his team in Swansea University for agreeing to undertake this work and for having produced such a thorough piece of research.

Their findings show that EU citizenship could be maintained after UK withdrawal, and that an associate citizenship could be possible without treaty change.

What will be essential is the political will to make it happen.

This ground-breaking work has already had recognition and support in Brussels and across Europe. I am confident that it will make a positive and constructive contribution to the negotiations on our future status as citizens. 


\section{Author biographies}

Dr Volker Roeben is a Professor of Public International Law at the Swansea University's College of Law and Criminology and an Adjunct Professor at the University of Turku, specialising in public international law, European Union law and comparative public law. He was educated at the University of Kiel, the University of California at Berkeley and the College of Europe Bruges. He was Senior Research Fellow at the Max Planck Institute for Comparative Public Law and International Law. He has held several visiting professorships in the United States and China, worked at the German Federal Constitutional Court, and served on several parliamentary advisory boards. He serves on the advisory board of the Max Planck Encyclopedia of Comparative Public Law.

Dr Jukka Snell is a Professor of European Law at the University of Turku and at Swansea University. Professor Snell was educated at the University of Helsinki and at King's College London. He has taught EU law at numerous institutions, and has written broadly on EU constitutional law and on the internal market. Professor Snell is a member of the Law Panel for Julkaisufoorumi, which is a project set up by the Federation of Finnish Learned Societies to evaluate research quality. He has given evidence to various committees of the Finnish Parliament on questions relating to European integration. Professor Snell serves as a Joint Editor for European Law Review.

Dr Pedro Telles is a Senior Lecturer in Law at Swansea University, Adjunct Professor at Griffith University (Australia) and a member of the European Union Committee of the Law Society. He was previously a Lecturer in Law and procurement law specialist at Bangor University. Before, he undertook his Ph.D in law at the University of Nottingham and practiced law in Portugal and Spain. Between 2012 and 2015 he co-organised Procurement Week, making it a leading international procurement with over 500 participants and is a founding member of the Institute for Competition and Procurement Studies.

Dr Petra Minnerop is a Senior Research Fellow at the Max Planck Foundation for International Peace and the Rule of Law, Heidelberg and she also teaches European Union Law at the Swansea University's College of Law and Criminology. She was educated at the Universities of Göttingen and Newcastle-upon-Tyne. She holds a Ph.D in international law from the University of Göttingen. She has held academic positions at the Max Planck Institute for Comparative Public Law and International Law and the Universities of Munich and Göttingen. She has practiced in European Union law, especially in the field of rights of workers, and worked for the German Foreign Office and the Permanent Representative of Germany to the United Nations.

Keith Bush QC is an Honorary Professor at Swansea University's College of Law and Criminology. He teaches public law through the medium of both English and Welsh languages and has established an innovative undergraduate module focusing on the law of devolution in the UK, within the context of federal, quasi-federal and supranational systems of multi-level governance generally.

Having spent over 20 years in private practice as a barrister, he joined the Welsh Government's legal service in 1999 and later served for 5 years as Chief Legal Adviser to the National Assembly for Wales. He is the author of the first text-book on public law in Welsh, "Sylfeini'r Gyfraith Gyhoeddus". He is Secretary of the Wales Public Law and Human Rights Association and Director of the annual Legal Wales Conference. 


\section{Executive summary}

This report has five principal findings on the protection of the status of Union Citizenship and their related rights post-Brexit. First, the key question in relation to providing this protection is whether Union Citizenship continues post-Brexit, or whether Brexit extinguishes Citizenship. The report considers that Continuity Union Citizenship ("Continuity") is the more convincing interpretation of European Union law and international law as it stands, but it also considers the alternative of creating the new status of Associate Union Citizenship of the European Union for British nationals ("Associate Union Citizenship") with related rights. Second, the report identifies two possible means of realising these models: i) legislation by the Union to clarify Continuity and ii) the Withdrawal Agreement between the EU and the UK enshrining Associate Union Citizenship or Continuity. Third, it is established that no revision of the Founding Treaties is needed, irrespective of the model followed. Fourth, UK citizenship law is highly flexible in line with the principle that individuals ought not to be stripped of citizenship against their will. Fifth, devolution in the UK entails that Wales may have a considerable responsibility to protect Union Citizenship rights post-Brexit.

\section{The options: Continuing Union Citizenship or creating the new status of Associate Union Citizenship}

The first option the report proposes can be called "Continuity Union Citizenship" or Continuity option. This Continuity option reflects the state of European Union law post the Treaty of Lisbon, whereby Union Citizenship is a fundamental status of individuals that cannot be taken away. However, the rights themselves contained within citizenship can change over time.

Thus, nothing in the status quo would change as the result of Brexit, neither for the Union in relation to citizens of British nationality on the territory of the Union nor for the Union citizens of EU-27 nationality in the UK. EU and UK action would clarify the existing legal situation, even if not strictly necessary. This continuity relates to Citizenship free movement rights that have been exercised or will have been exercised at the time the UK withdrawal becomes effective. The dormant rights of those residing in their own Member State at the time of withdrawal are different and protected only as to the core right of residing somewhere in the territory of the EU.

Continuity also reflects the state of international law. The 1969 Vienna Convention on the Law of Treaties (VCLT) will be binding on all remaining Member States, the UK, and the EU itself post Brexit. It ensures that the status and rights of those EU citizens resident in the territory of the Union and those resident in the UK will continue. Art. 70(1)(b) of that Convention provides that 'legal situations' created during the currency of the Treaties continue after the withdrawal. That covers the situation of nationals of Member States that have been admitted to and reside in another member pursuant to the Treaties. These go on after withdrawal unchanged. Art. 70(1)(b) of the Vienna Convention also continues 'rights' of individuals derived from treaty. As the fundamental Case 26/62 van Gend en Loos makes clear, the Founding Treaties of the EU grant rights directly to individuals. This interpretation of the Convention that ongoing situations and rights continue is supported by the overriding objective of ensuring legal certainty and preventing withdrawals from treaty from having any retroactive effect. It is also supported by state practice.

There is, however, a reading of European Union law and Art. 70(1)(b) of the Convention that the exit of a Member State pursuant to Art. 50 TEU extinguishes all rights of individuals created by the 
Founding Treaties. If one were to adopt that reading, then European Union law and international law would at least demand that a treaty be negotiated on Associate Union Citizenship, which the report discusses as an alternative model. In this second case, the status that emerges as Associate Union Citizenship and the bundle of rights that go with it will have to be defined. EU action would have constitutive effect. Whether there should be any distance from the bundle of rights that come with full Citizenship is a political question.

A third option is an individual opt-in for British nationals, conferring an exclusively personal status. This option is the furthest from the law as it stands and will therefore not be explored in this report.

\section{Legislation to enshrine Continuity Citizenship}

The Union could legislate on Citizenship post-Brexit. The available competences, set forth in Arts. 2124 TFEU, empower the Union to legislate to that effect.

Such legislation will only have a clarificatory role in the case of Continuity as a matter of logic. This legislation to continue citizenship would essentially extend the law as laid down in Directive 2004/38 and Regulation 492/2011, and would also codify the rights that are recognised in the case law of the Court of Justice of the European Union. It would protect the rights of permanent residents and, for a defined period of time, the legitimate expectation of others to obtain that status. It could also protect dormant rights.

The legislation would protect British nationals in the EU. It would not, however, have any binding effect in the UK post-Brexit. While Continuity does not change anything, the best way to protect and make those rights of EU-27 nationals enforceable is to include them in the Withdrawal Agreement even though it is not technically necessary.

\section{The Withdrawal Agreement as a means of achieving either Continuity or Associate Union Citizenship}

The alternative means is a treaty between the EU and the UK, the so-called Withdrawal Agreement. That treaty will be binding on the EU and the UK, post-Brexit, as international law. Two new statuses could be created in the treaty. Associate Union Citizenship for British nationals could be matched by an Associate British Citizenship for Union citizens from the remaining Member States.

This agreement should be based on reciprocal protection of exercised citizenship rights of British nationals in the EU and for EU-27 nationals in the UK. Dormant rights to free movement could be protected in the Agreement for a defined period of time after the entry into force of the Withdrawal Agreement. The political rights would be part of the whole package of rights included in the Agreement. Thus, residents on the territory of the Union would be allowed to vote and stand for the EP in their host Member States, represented by the members of parliament allotted to that Member State. Union citizens resident in the UK would vote in the Member State of their last residence.

The Agreement will have to have two pillars. The first pillar comprises the rules that concern British nationals in the Union territory. These rules will automatically become part of Union law and as such be directly applicable before the courts of the remaining Member States. Directives and regulations to implement the Agreement might still be needed, though, given the limitations of direct effect and the need for certainty and clarity. The second pillar comprises the rules concerning EU-27 nationals 
in the UK. Under UK constitutional law, these international rules will have to be transformed into national legislation to become internally applicable.

UK citizenship law is highly flexible. It has created differentiated statuses with related rights. An important principle underlying that flexibility is that individuals may not be stripped of their citizenship as result of territorial changes. That principle should apply to the protection of Union Citizenship.

Judicial protection of these treaty-based rights would also be organised along the lines of this twopillared structure. The national courts of the EU-27 would adjudicate the rules applying in the Union territory. They would be able to refer questions to the Court of Justice of the European Union under Art. 267 TFEU. British courts would adjudicate the rules applying in the UK. They would no longer be able to access the Court of Justice of the European Union.

This has to be reinforced by a mechanism to settle disputes that may arise between the EU and the UK relating to the agreement. Two such mechanisms are conceivable. An international court of arbitral tribunal may be created. The agreement would then have to include provision to protect the exclusive jurisdiction of the Court of Justice of the European Union for the interpretation of EU law. Alternatively, the agreement could confer jurisdiction on the Court.

\section{No need for revising the Founding Treaties}

This report furthermore concludes that neither Continuity nor Associate Union Citizenship require any revision of the Founding Treaties. The provisions on Union Citizenship, Art. 20-25 of the Treaty on the Functioning of the European Union, are to be interpreted as not standing in the way of protecting citizenship status and rights post-withdrawal. That protection will concern persons that are nationals of a former if not current Member State, and not interfere with the exclusive competence of the Member States over who obtains their nationality and thereby Union Citizenship. However, it is conceivable that there could be included in the Withdrawal Agreement provision to amend the Founding Treaties. That would make it a so-called mixed agreement that needed to be ratified by all remaining Member States.

\section{UK citizenship law and devolution}

The report also finds that Wales, as other parts of the UK, has considerable devolved powers to realise a non-discriminatory protection of the rights of EU-27 nationals, basing its rules on access to public services on residence rather than nationality. However, the UK government currently retains the powers over immigration. 


\section{Report}

Table of Cases and materials, bibliography, and table of abbreviations

Table of cases of the Court of Justice of the European Union

Alimanovic, Case C-67/14, 15 September 2015

Baumbast, Case C-413/99, 17 September 2002

Bidar, Case C-209/03, 15 March 2005

Carpenter, Case C-60/00, 11 July 2002,

Chavez-Vilchez, Case C-133/15, 10 May 2017

Commission v Belgium, Case C-408/03, 24 May 2011

Commission v Germany, Case C-441/02, 27 April 2006

Delvigne, Case C-650/13, 6 October 2015

Dereci, Case C-256/11, [2011] ECR I-11315

Diatta, Case C-267/83, 13 February 1985

Eind, Case C-291/05, 11 December 2007

Förster, Case C 158/07, 18 November 2008

Gebhard, Case C-55/94, 30 November 1995

Grzelczyk, Case C-184/99, 20 September 2001

Horst v Bundesknappschaft, Case C-6/75, [1975] ECR 26

Hungary v Slovakia, Case C-364/10, 16 October 2012

Jany, Case C-268/99, 20 November 2001

Jessy Saint Prix, Case C-507/12, 19 June 2014

McCarthy, Case C-202/13, 18 December 2014

Nicolas Bressol, Case C-73/08, 13 April 2010

O. and B., Case C-456/12, 12 March 2014

Olazabal, Case C-100/01, 26 November 2002

Orfanopoulos , Cases C-482/01 and C-493/01, 29 April 2004

Oulane , Case C-215/03, 17 February 2005 
Parliament v. Council, Case C-658/11, 24 June 2014

Parliament v. Council, Case C-263/14, 24 June 2016

Parliament and Commission v. Council, Joined Cases C 103/12 and C 165/12, 26 November 2014.

Peter Brey, Case C-140/12, 19 September 2013

Petruhhin, Case C-182/15, 6 September 2016

Racke GmbH and Co, Case C-162/96, [1998] ECR I-3688

Rottmann, Case C-135/08, [2010] ECR I-1449

Rutili, Case C-36/75, 28 October 1975

Schrems, Case C-362/14, 6 October 2015

Spain v United Kingdom, Case C-145/04, [2006] ECR I - 7961

U., Case C-420/15, 31 May 2017

Van Gend en Loos, Case 26/62, [1962] ECR 2

Opinion 2/91 (Convention № 170 of the International Labour Organization concerning safety in the use of chemicals at work), [1993] ECR I-1061.

Opinion 1/00 (European Common Aviation Area), [2002] I-3493

Opinion 2/13 (European Convention of Human Rights), 18 December 2014

\section{Table of EU legislation and EU materials}

Directive 2004/38 of 29 April 2004 on the right of citizens of the EU and their family members to move and reside freely within the territory of the Member States, OJ L 229/43

Directive 2014/54/EU of 16 April 2014 on measures facilitating the exercise of rights conferred on workers in the context of freedom of movement for workers, OJ L 128/8.

Regulation 883/2004 of 29 April 2004 on the coordination of social security systems, OJ L 166/1 Regulation 492/11 of 5 April 2011 on freedom of movement for workers within the Union, OJ L $141 / 1$

Regulation (EU) No 211/2011 of the European Parliament and of the Council of 16 February 2011 on the citizens' initiative, [2011] OJ L 65/1), consolidated version 01/07/2014.

Treaty amending, with regard to Greenland, the Treaties establishing the European Communities, with Protocol on special arrangements, [1985] OJL 29/1 
Council Decision 2014/137/EU of 14 March 2014 on relations between the European Union on the one hand, and Greenland and the Kingdom of Denmark on the other, OJ L 76/1.

Commission, Opinion, Status of Greenland, 2 February 1983, EC Bulletin, Supplement 1/83, 20

Praesidium de la Convention européenne, Note du Praesidium à la Convention: Titre XL'appartenance à I'Union, CONV 648/03, 2 April 2003, at http://www.cvce.eu/content/publication/2013/8/5/2551b42a-e0ce-49d4-857a4325e1154e2e/publishable fr.pdf

EEA Agreement, [1994] OJ No L 1/3

\section{Bibliography}

H. Ascenio, Art. 70, in Corten \& Klein (eds), Commentary on the Vienna Convention on the Law of Treaties (OUP, 2011)

C. Barnard, The substantive law of the EU ( $5^{\text {th }}$ ed, OUP, 2016)

Sir G. Fitzmaurice, The Law and Procedure of the International Court of Justice vol I (Cambridge: Grotius, 1986)

D. Gosewinkel, Schutz und Freiheit? Staatsbürgerschaft in Europa im 20. und 21. Jahrhundert (Suhrkamp, 2016)

L. Helfer, 'Terminating Treaties', in D. Hollis (ed), The Oxford Guide to Treaties (Oxford University Press, 2012), 634

D. Kochenov, 'The Essence of EU citizenship emerging from the last ten years of academic debate: beyond the cherry blossoms and the moon?', (2013) 62 International and Comparative Law Quarterly 97

A. Lansbergen \& J. Shaw, 'National membership models in a multilevel Europe', (2010) 8 International Journal of Constitutional Law 50

N. Luhmann, Law as a social system (Oxford University Press, 2004)

A. Nollkaemper, 'Some Observations on the Termination of Treaties and the Reach of Art. 70', in I.T. Dekkers \& H.H. Post (eds), On the Foundation and Sources of International Law (Kluwer, 2003), 187

N. N. Shuibhne, 'The Developing Legal Dimensions of Union Citizenship', in: A. Arnull/D. Chalmers (eds.), The Oxford Handbook of European Union Law (Oxford University Press, 2017) 477

K.S. Sik, 'The Concept of Acquired Rights in International Law', (1977) 120 Netherlands International Law Review 137

M.E. Villiger, Commentary on the VCLT (Brill, 2009) 


\section{Table of abbreviations}

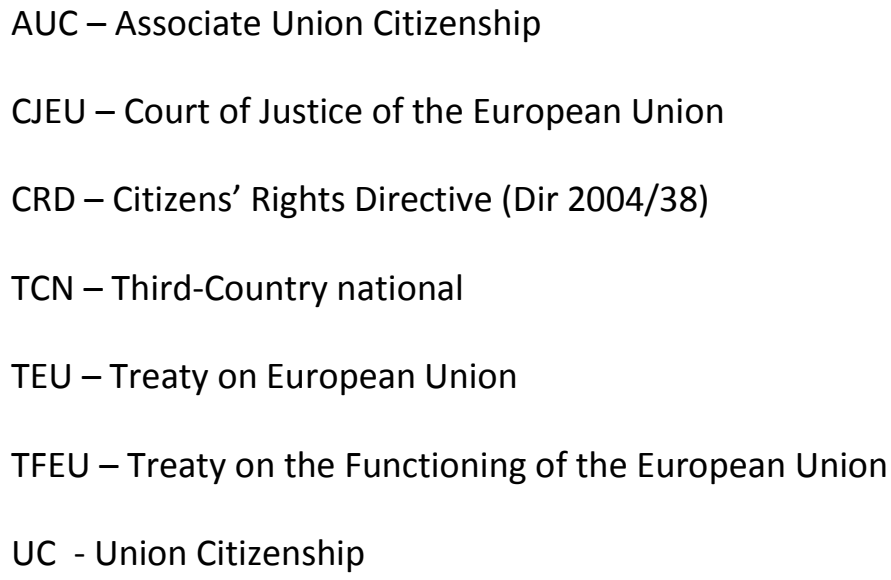

\section{TABLE OF CONTENTS}

THE FEASIBILITY OF ASSOCIATE UNION CITIZENSHIP FOR UK CITIZENS POST-BREXIT...ERROR! BOOKMARK NOT DEFINED.

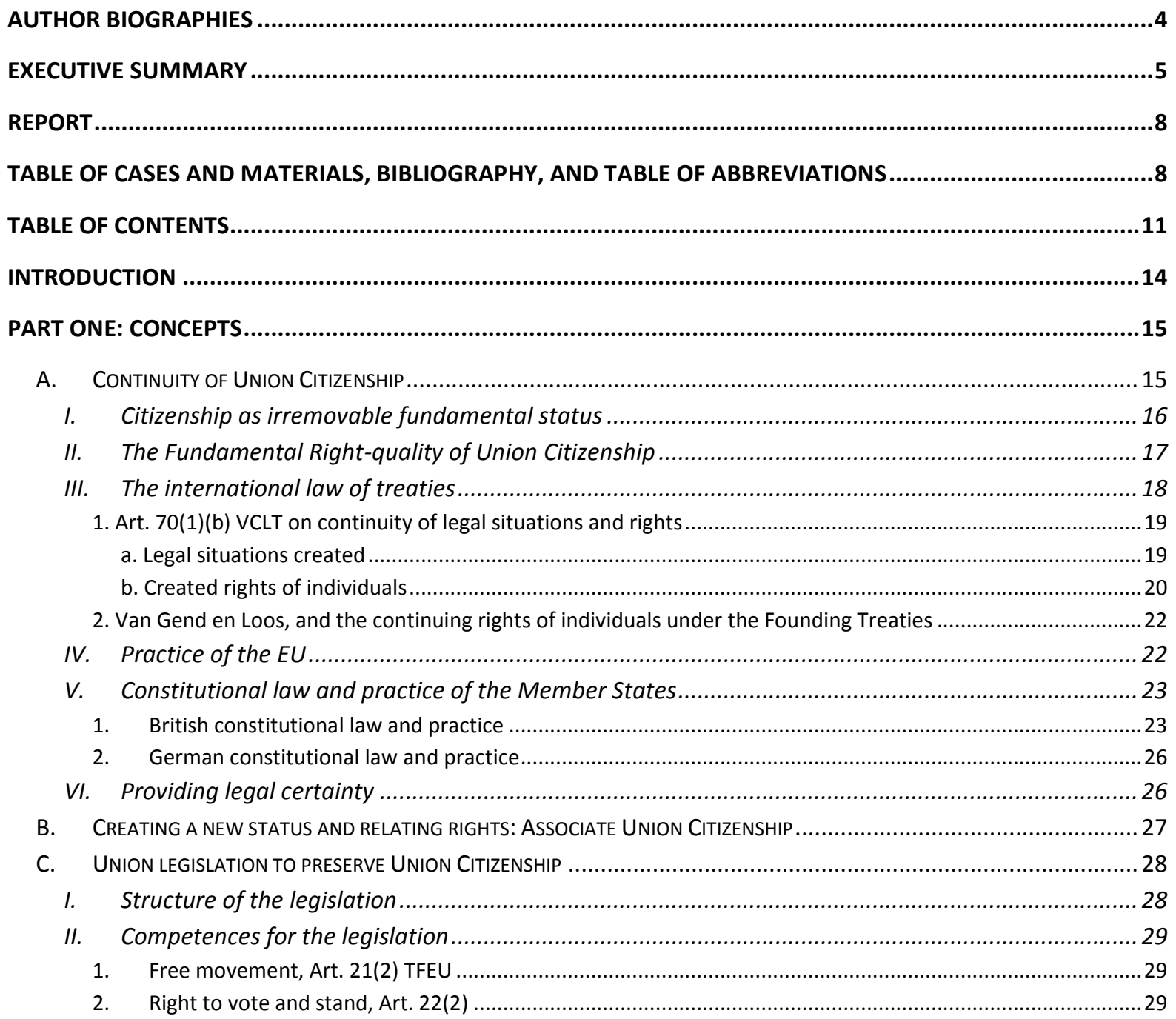




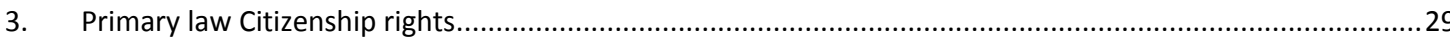

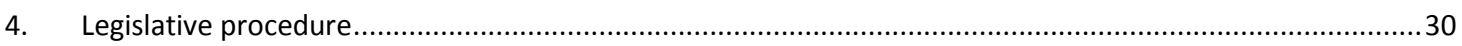

III. Ensuring equal treatment of all Union citizens ...................................................................... 30

IV. Is legislating on the Citizenship of British nationals compatible with international law? ....................30

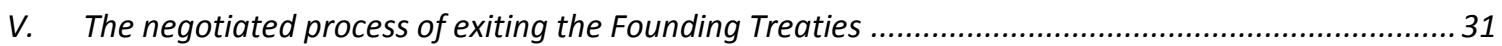

D. The Withdrawal Agreement between the EU AND the UK on Associate CitizenShip .....................................3

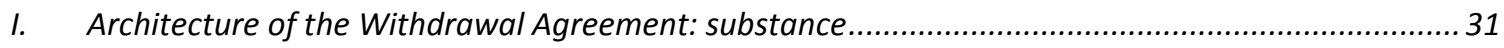

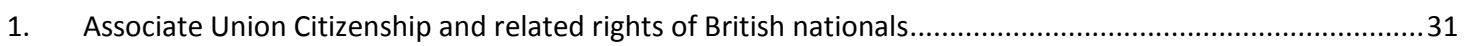

2. Associate British Citizenship and related rights of EU-27 nationals..............................................................32

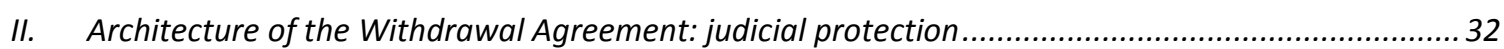

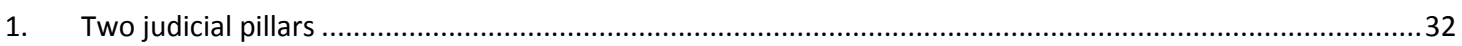

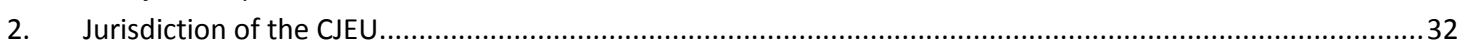

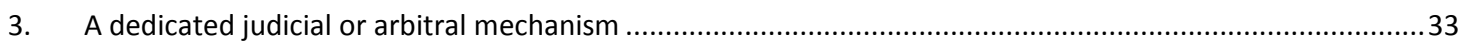

III. The competence of the Union for a Withdrawal Agreement with the UK......................................... 33

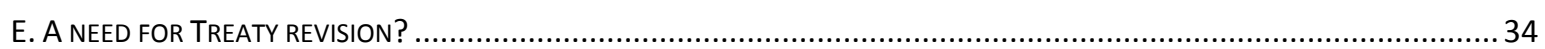

I. Art. 20(1)(2) TFEU - Union Citizenship derived from the nationality of a Member State ...................34

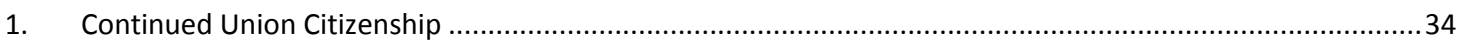

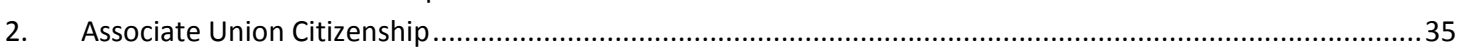

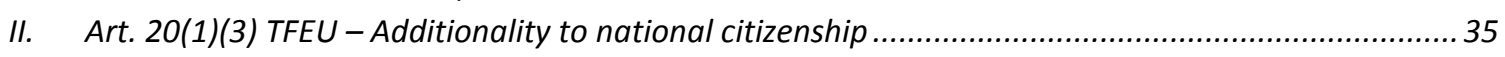

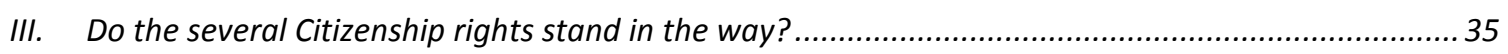

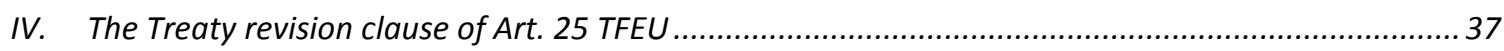

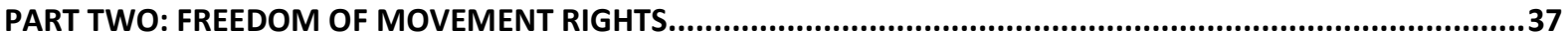

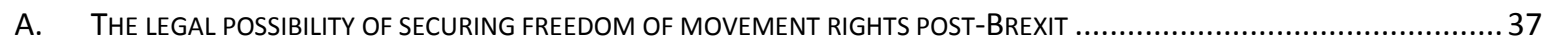

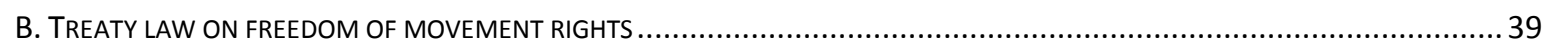

C. FUNDAMENTAL RIGHTS AND GENERAL PRINCIPLES OF EUROPEAN UNION LAW FOR RULE-MAKING FOR THE TIME POST-BREXIT 41

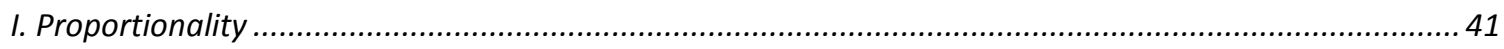

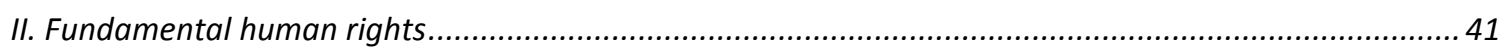

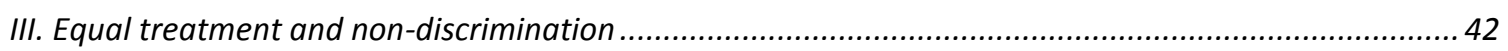

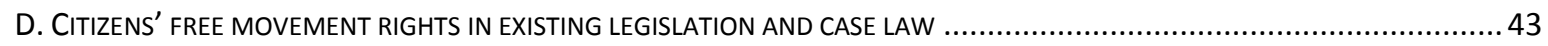

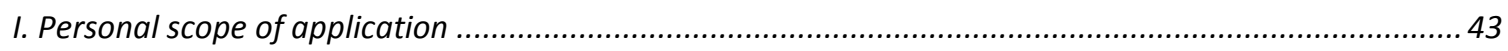

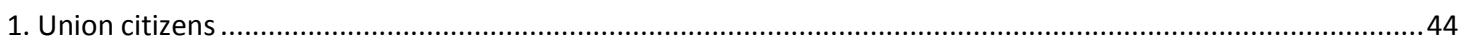

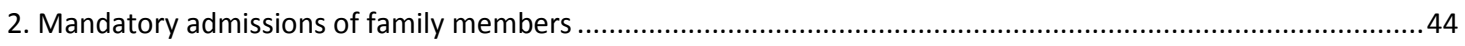

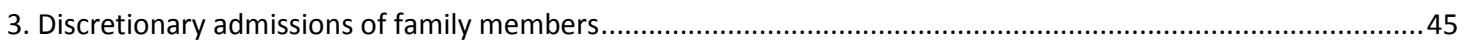

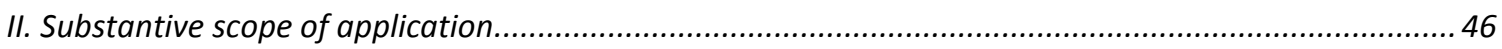

1. The right to leave the home member State and to return to the home member State....................................46

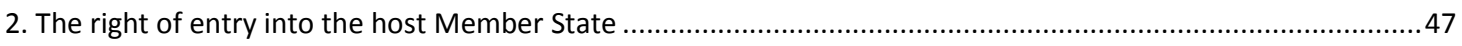

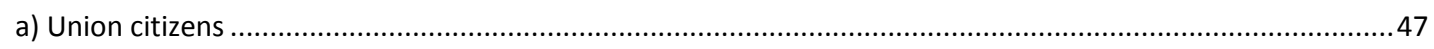

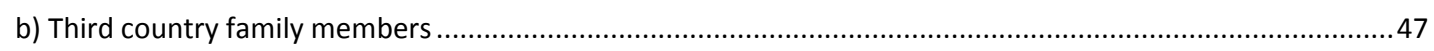

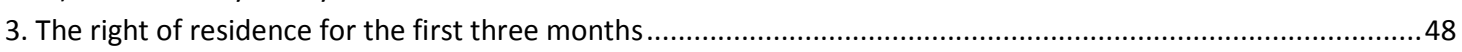

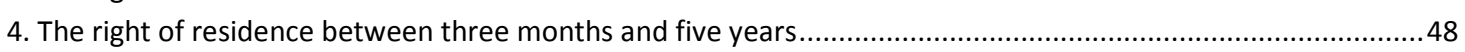

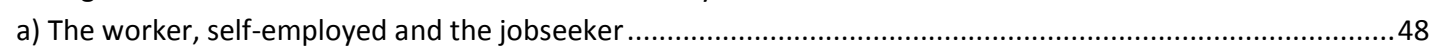

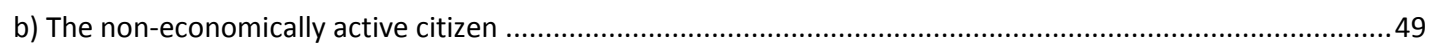

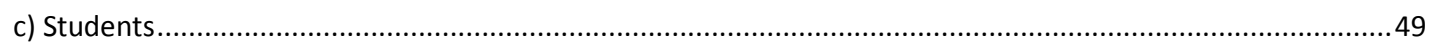

5. The right of permanent residence, duration of residence, continuity and exceptions ..................................... 49

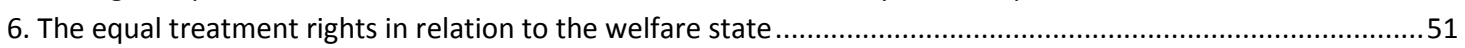

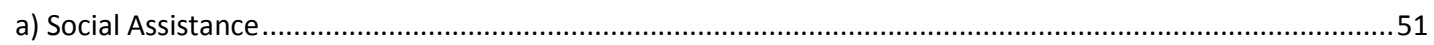

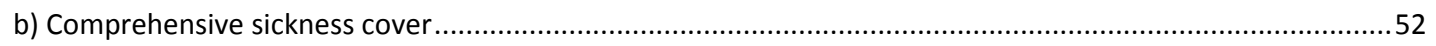

7. Administrative formalities for the right of residence of Union citizens ..........................................................53

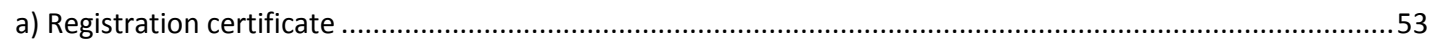

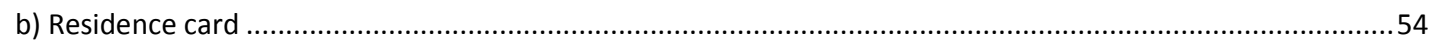




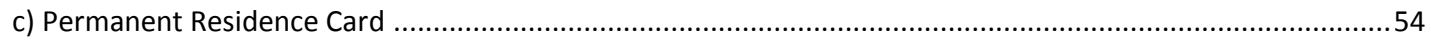

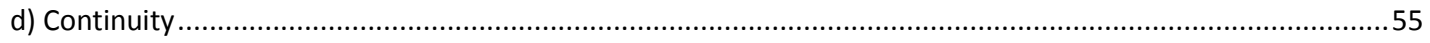

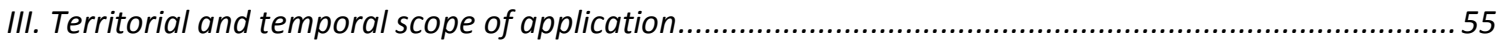

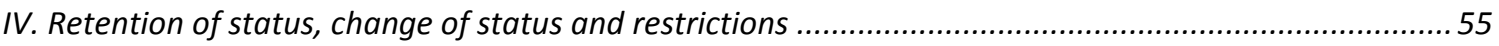

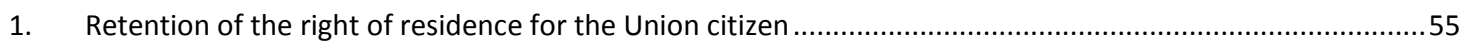

2. Retention of the status of worker or self-employed person ....................................................................55

3. Retention of the derived right to reside in case of death or departure of the primary Union citizen..................56

4. Retention of the derived right to reside in case of divorce, annulment of marriage or termination of registered

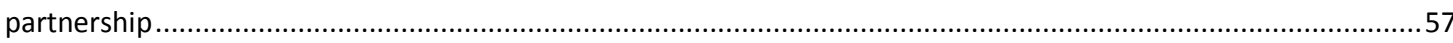

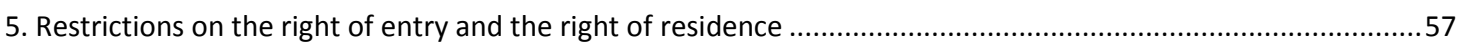

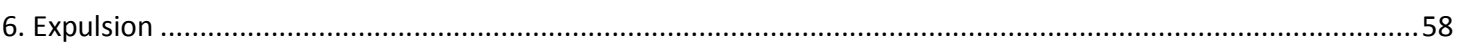

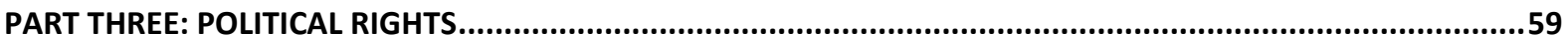

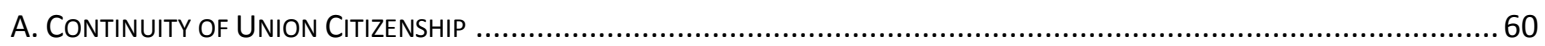

I. Right to vote and stand for European Parliament and municipal elections (Art 22 TFEU) ................60

II. Right to diplomatic and consular representation (Art. 23 TFEU) .....................................................6 60

III. Citizen's initiative, petition to the European Parliament, application to the European Ombudsman and reply from the Union bodies in the same language (Art. 24 TFEU and Art. 11 TEU).................................61

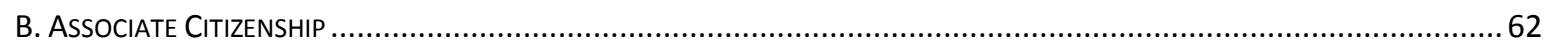

I. Right to vote and stand for European Parliament and municipal elections (Art 22 TFEU) .................62

II. Right to diplomatic and consular representation (Art. 23 TFEU) ....................................................62

III. Citizens' initiative, petition to the European Parliament, application to the European Ombudsman and reply from the Union bodies in the same language (Art. 24 TFEU and Art. 11 TEU).........................62

PART FOUR: DEVOLUTION (ENSHRINING CITIZENSHIP RIGHTS IN THE LAW OF WALES) .............................63

A. THE ROLE OF DEVOLVED GOVERNMENT IN RELATION TO RIGHTS ASSOCIATED WITH CITIZENSHIP....................................63

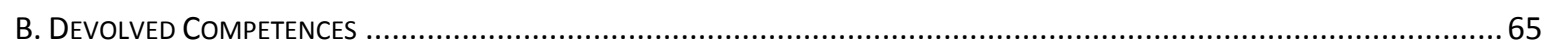

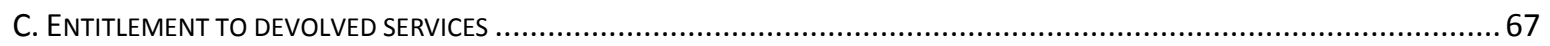

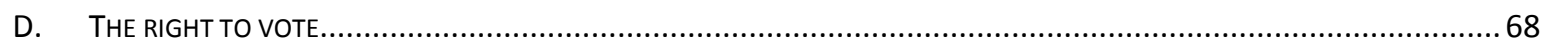

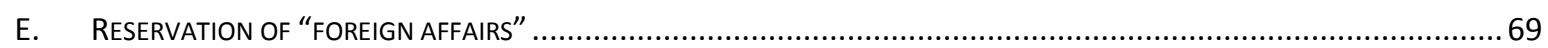




\section{INTRODUCTION}

In line with the aspiration to create a 'Europe for citizens' dating back to the early 1970s, the 1992 Maastricht Treaty inserted a new Part Two into the EC Treaty, entitled 'Citizenship of the Union'. It established 'Citizenship of the Union' and listed a number of related specific rights. After revision by the 2007 Lisbon Treaty, 'Citizenship of the Union' is now contained Part Two of the Treaty on the Functioning of the European Union (TFEU). Art. 20(1) TFEU provides "Citizenship of the Union is hereby established" and it guarantees that "every person holding the nationality of a Member State shall be a citizen of the Union". Art. 20(2) TFEU then lists rights that Union Citizenship encompasses, although that list is not exhaustive.

With the withdrawal of the UK from the EU becoming effective, the Treaties will cease to apply between that State and the remaining Member States. That could also affect the Union Citizenship of British nationals and nationals of the EU-27. This report explores whether and how this status and the related rights are protected post-Brexit.

The report has four parts. Part One distinguishes the concepts of a continuing Union Citizenship and a new Associate Union Citizenship. Part Two discusses the implementation of citizens' free movement rights, and Part Three the implementation of citizens' political rights. Part Four turns to the competences of Wales, as a devolved administration, to act on citizens' rights. 


\section{PART ONE: CONCEPTS}

This Part distinguishes continuing Union Citizenship post-Brexit (A) from the alternative new status of 'Associate Union Citizenship' as means of safeguarding most if not all of the rights of Union Citizenship for British nationals (B). The report concludes that Continuity accords with the convincing reading of European Union and international law, but it also explores the alternative of Associate Union Citizenship. A third -option is the furthest from the law as it stands and will therefore not be explored in this report. The Part then introduces Union legislation as a means to protect Continuity in a legally certain manner Continuity for British nationals (C). It furthermore discusses the Withdrawal Agreement between the EU and the UK as the means to protect, on a reciprocal manner, the status and rights of Union citizens of British nationality and of EU-27 nationality (D). It concludes that no revision of the Founding Treaties is needed to realise either option (E).

\section{A. Continuity of Union Citizenship}

With the withdrawal of the UK from the Founding Treaties becoming effective two years after the notification of the intention to withdraw, the UK will become a non-Member State. Its nationals will become so-called third country nationals (TCNs). The key question then is whether or not Brexit extinguishes their Union Citizenship.

The first option this report discusses can be called Continuity Union Citizenship ('Continuity'). This Continuity reflects the state of European Union law post the Treaty of Lisbon, whereby Union Citizenship is the fundamental status of individuals that cannot be taken away, even though the rights themselves contained within citizenship can change over time. It also reflects the requirements of the Vienna Convention of the Law of the Treaties. Thus, nothing in the status quo would change as the result of Brexit, neither for the Union citizens of British nationality on the territory of the Union nor for the Union citizens of EU-27 nationality in the UK. EU and UK action would clarify the existing legal situation, even if not strictly necessary. Continuity encompasses rights that citizens currently enjoy. It clearly comprises the exercised free movement rights, of citizens who have taken up residence ${ }^{1}$ in a Member State other than their own, under the conditions of primary and secondary EU law. But it also comprises the essence of the free movement right that has not yet been exercised and remains dormant, which is the right of citizens to continue to reside somewhere in the territory of the Union.

Legally, Continuity rests on two grounds in European Union law. First, under the Treaties, Citizenship is the fundamental status that cannot be taken away from the individual by general measures (I). Second, with the entry into force of the Charter of Fundamental Rights of the EU, the Citizenship rights have acquired a fundamental rights-quality; the status of Citizenship itself acquires a fundamental right-quality as a general principle of Union law within the meaning of Art. 6(3) TEU (II). But Continuity also rests on the international law that will be binding on the EU, the UK and the remaining Member States post-Brexit. Art. 70(1)(b) of the 1969 Vienna Convention on the Law of Treaties ensures that "legal situations" and "rights" created in the execution of the Founding Treaties are ongoing. That covers Union Citizenship and the related rights of individuals (III). The practice of the EU itself (IV) and the constitutional practice of the Member States confirm that citizenship continues throughout territorial changes (V). Although not strictly necessary, action of

\footnotetext{
${ }^{1}$ In addition to frontier workers.
} 
the EU and the UK will make the exercise of the continuing rights post-Brexit more secure. The principle of legal certainty demands such action (VI).

\section{Citizenship as irremovable fundamental status}

Since Grzelczyk, ${ }^{2}$ the Court of Justice of the European Union (CJEU) has consistently referred to Union Citizenship as the 'fundamental status' of each individual. Treaty-based Citizenship is a fundamental status of the individual, and the related rights, enshrined in Arts. 20-24 TFEU, are directly applicable individual rights that receive judicial protection.

Removing, on a general basis, Union Citizenship is not a power vested in any Member State (nor in the EU). In fact, even the power of a Member State to remove Union Citizenship on an individualised basis is severely constrained. Thus, in Rottmann, the CJEU found that the Member States, have to take the interests of the Union into account and ensure that the individual concerned does not lose his/her Union Citizenship when stripping that individual of their nationality. ${ }^{3}$ That is in line with the constitutional law of Member States. ${ }^{4}$

The constant case-law of the CJEU protects Union Citizenship, the status itself, indirectly, by protecting, directly, the substance of the rights relating to it against interference by the Member States. It is then all the more true that Union Citizenship is protected against measures that remove the status directly, and, thereby as necessary consequence, all the rights pertaining to that status.

'Continuity' means that Union Citizenship once conferred cannot be taken away by any general measure. While the Member States are competent to confer that status, the reverse is not true. No Member State has the general power to remove Union Citizenship. On that reading, Art. 50(1) TEU is not an implied restriction on Art. 20(1) TFEU. It is merely the power of each Member State to withdraw from the Treaties, and to end their applicability on the international law plane between itself and the remaining Member States.

Thus, Union Citizenship of both British and EU-27 nationals will continue unchanged post-Brexit, although the various rights relating to that Citizenship may be affected in one way or another by the consequences of Brexit, creating the need for the EU and the UK to take proportionate protective action. Clearly, the Citizenship rights that have been exercised will continue, including the free movement rights that Union citizens of EU-27 nationality have exercised in moving to the UK and those of UK nationality in moving to one of the remaining Member States. In Chavez, the CJEU has recently reiterated that the essence of not yet exercised citizenship rights is protected. ${ }^{5}$ That essence is to reside somewhere in the territory of the Union, including the own Member State of the

\footnotetext{
${ }^{2}$ Case C-184/99, [2001] ECR I-6193, para 31.

${ }^{3}$ Case C-135/08, [2010] ECR I-1449.

${ }^{4}$ Art. 16 of the Basic Law of the Federal Republic of Germany rules out any general measures stripping individuals of their citizenship, but it does not preclude doing so for individualised and proportionate reasons. Art. 26(1) and (4) of the Portuguese Constitution also considers citizenship to be a fundamental right that can only be stripped in a very limited set of circumstances.

${ }^{5}$ Case C-133/15, Chavez-Vilchez, 15 May 2017, para 63: "the effectiveness of Union citizenship would ... be undermined, if, ..., that citizen would be obliged in practice to leave the territory of the European Union as a whole, thus depriving him of the genuine enjoyment of the substance of the rights conferred by that status [of Citizenship].
} 
citizen, ${ }^{6}$ retaining the chance to exercise the free movement rights later. Under what conditions and for how long these dormant rights of Union citizens of British nationality currently residing in the UK in regard to their potential, future exercise will continue to be protected post Brexit is ultimately a political decision.

\section{The Fundamental Right-quality of Union Citizenship}

The entry into force of the Charter of Fundamental Rights of the European Union ('the Charter') has added the quality of fundamental rights to the rights relating to Union Citizenship. To the Treaty rights there now correspond the fundamental rights laid down in Chapter V of the Charter on 'Citizens' rights'. The normativity of the Treaty and of the Charter is mutually reinforcing.

Although the Charter does not qualify Citizenship as such as a fundamental right, Chapter V of the Charter, entitled "Citizens' rights", also enshrines the principal rights of Citizenship as fundamental rights: Art. 39 guarantees the fundamental right of citizens to vote and stand for the EP. Art. 15(2) guarantees the freedom of every citizen to seek employment, to work, to exercise the right of establishment and to provide services in any Member State. Art. 45(1) enshrines the right of all citizens, including the non-economically active, to reside in the territory of the Union as a fundamental right.

These fundamental Citizenship rights are ultimately grounded in the foundational fundamental right of human dignity.

The CJEU has developed, in its case law, a doctrine that combines the Treaty Citizenship rights, Arts. 20-24 TFEU, with the fundamental rights of the Charter. Union action and Member State action within the scope of application of the primary and secondary Union law on Citizenship must also comply with all Charter fundamental rights. Thus, in Delvigne, the Court linked Art. 22 TFEU with Art. 39 of the Charter of Fundamental Rights, the fundamental right to vote and stand for the European Parliament. ${ }^{7}$ In Petruhhin, the Court linked Art. 21, the free movement of citizens, with Art. 19(2) of the Charter of Fundamental Rights of the EU (CFR), the fundamental right not to be expelled to a third country where there is a risk of inhuman treatment. ${ }^{8}$ In Chavez, the Court reinforced the derived residence rights under Art. 20 TFEU of TCNs who are the primary carers of children having Union Citizenship, by referring to the fundamental rights of the child guaranteed in Art. 24 CFR.

Several constitutions of the Member States indeed include a fundamental right of individual citizens not to be stripped against their will of their citizenship or indeed to be extradited to another jurisdiction. ${ }^{9}$ It is then only a small step to recognise that the constitutional traditions of the Member States recognise that the retention of Union Citizenship itself is a fundamental right, on the basis of a

\footnotetext{
${ }^{6}$ Chavez-Vilchez, note 5 , para 63.

${ }^{7}$ Case C-650/13, Delvigne, 6 October 2015.

${ }^{8}$ Case C-182/15, Petruhhin, 6 September 2016. Individual lawful residence against collective termination is also protected as fundamental right, Art. 19(2) of the Charter, as well as a human right under Art. 1 of Additional Protocol No 7 to the European Convention of Human Rights.

${ }^{9}$ For instance Art. 16 of the Basic law of Germany. Art. 26(1) and (4) of the Portuguese Constitution also considers citizenship to be a fundamental right that can only be stripped in a very limited set of circumstances.
} 
weighted or qualified comparative analysis of the constitutions of the Member States, pursuant to Art. 6(3) TEU.

Art. 52(1) of the Charter stipulates that the Member States must "respect the essence of those rights" ${ }^{10}$ Stripping individuals of their Union Citizenship by leaving the Union interferes with that essence. The legal consequence is that that interference is unlawful, does not produce legal effect, and thus that the Citizenship continues.

\section{The international law of treaties}

Continuity is also provided for in international law. The universal codification of that law, the 1969 Vienna Convention on the Law of Treaties, applies to the 2007 Treaty of Lisbon. It will be binding on all remaining Member States, the UK and the EU itself post-Brexit.

The Vienna Convention applies to a Member State withdrawing from the Founding Treaties. Art. 50 TFEU fully follows the template that the Convention designs for withdrawal from any substantive treaty. It was the intention of the drafters of Art. 50 TEU to follow that template. The clause on exiting the European Union, which is now Art. 50 TEU, was first drafted by the Constitutional Convention and included in the Constitutional Treaty. The commentary on that clause makes that intention clear. ${ }^{11}$ While the Constitutional Treaty never entered into force, the intergovernmental conference on the Lisbon Treaty inserted the exit clause without any change into the revised Treaty on European Union, as a new Art. 50. Art. 50 TEU therefore needs to be read in the light of that Convention whose rules supplement the skeleton provision in Art. 50 TEU.

The overriding objective of Art. 70 of the Vienna Convention, and hence Art. 50 TEU, is to achieve legal certainty and non-retroactivity of a State exiting from a treaty. All retroactive effects are strictly ruled out. Art. 70(1)(b) of the Convention governs the consequences of withdrawals by states parties from multilateral treaties. Legal situations created during the currency of the treaty continue after its end. It is the ongoing responsibility of states to comply with obligations in relation to acts taken with regard to citizens of the nationality of another Member State. In addition, individual rights created by the treaty continue.

In the case of the EU, the most important legal situations created are the millions of fundamental statuses of Union Citizenship, to which the defined Citizenship rights relate. Art. 70(1)(b) VCLT provides the legal basis for the continuity of these legal situations created in the execution of the

\footnotetext{
${ }^{10}$ Emphasis added.

11 “Finalement, l'Art. 46 relatif au retrait volontaire d'un État membre de l'Union est une disposition nouvelle. Elle reconnaît expressément la possibilité pour chaque Etat membre de se retirer de I'Union européenne s'ils en décide ainsi. La procédure de retrait s'inspire en partie de celle prévue dans la Convention de Vienne sur le droit des traités, tout en prévoyant la possibilité pour l'Union et l'État membre concerné de conclure un accord régissant les modalités de son retrait et établissant le cadre de leurs relations futures". Praesidium de la Convention européenne, Note du Praesidium à la Convention: Titre X - L'appartenance à l'Union, CONV 648/03, 2 April 2003, at http://www.cvce.eu/content/publication/2013/8/5/2551b42a-e0ce-49d4-857a$\underline{4325 \mathrm{e} 1154 \mathrm{e} 2 \mathrm{e} / \text { publishable fr.pdf. }}$
} 
Founding Treaties, post-Brexit. It is also the basis for the corresponding rights of individuals that arise directly from the Founding Treaties under the case-law founded on van Gend en Loos.

Admittedly, Art. 70(1)(a) VCLT has attracted considerable and controversial attention in the context of Brexit. ${ }^{12}$ The interpretation of that critical provision put forward here therefore has to be justified in some depth in what follows:

\section{Art. 70(1)(b) VCLT on continuity of legal situations and rights}

Art. 70(1)(b) VCLT provides rules to ensure that withdrawal shall have no retroactive effect: ${ }^{13}$ withdrawal "does not affect any right, obligation, or legal situation of the parties created through the execution of the treaty prior to [withdrawal]". ${ }^{14}$ The ILC saw these rules as a matter of legal logic. The Convention creates an obligation for both the withdrawing State and the remaining States Parties to comply with the treaty after its end. ${ }^{15}$ These supplementary rules apply whenever the substantive treaty does not stipulate. ${ }^{16}$

'Legal situations, rights and obligations of the parties' and 'created in the execution' are the two terms defining the scope of the provision. ${ }^{17}$ These terms are to be interpreted through the canon set forth in Art. 31 and 32 of the Vienna Convention, that is the wording, context, and object and purpose of Art. 70, taking into account other relevant international rules as well as state practice.

\section{a. Legal situations created}

The Convention primarily grounds the continuity of the status quo in the third ground of Art. 70(1)(b) VCLT on legal situations created in objective law during the currency of the Treaties. That serves as a catch-all clause to the effect that withdrawal has exclusively prospective effects. The State's act has created a legal situation in respect of which there is the ongoing obligation to comply

\footnotetext{
${ }^{12}$ See UK House of Lords, European Union Committee, 10th Report of Session 2016-17, HL Paper 82, Brexit: acquired rights, December 2016, p. 25, referring to the evidence from Professor Vaughan Lowe QC (AQR0002 and AQR0003); EP, DG Internal Policies, Study, 'The impact and consequences of Brexit on acquired rights of EU citizens living in the UK and British citizens living in the EU-27', PE 583.135.

${ }^{13}$ A. Nollkaemper, 'Some Observations on the Termination of Treaties and the Reach of Art. 70', in I.T. Dekkers/H.H. Post (eds), On the Foundation and Sources of International Law, 2003, 187; F. Capotorti, 'L'extinction et la suspension des traités', (1971) 134 RdC 417-587.

${ }^{14} \mathrm{Art.} 70(1)(b)$ VCLT, with added emphasis. Technically, the first paragraph of Art. 70 deals with treaty-termination, but the second paragraph extends these rules to withdrawal.

${ }^{15} \mathrm{H}$. Ascenio, Art. 70, in Corten \& Klein (eds), Commentary on the VCLT (OUP, 2011), para 4. The ILC Commentary leaves the question of the source of that obligation open.

${ }^{16}$ See Compliance Committee of the Kyoto Protocol, Canada's withdrawal from the Kyoto Protocol and the consequences for its reporting obligations. CC/EB/25/2014/2, 20 August 2014, para 21 (applying Art. 70(1)(b) VCLT in the absence of provision in the Kyoto Protocol). Canada withdrew from the Kyoto Protocol under Art. 27, Depository Notification, C.N. 796.20121 TREATIES-1, 16 December 2011. It remained a party to the UNFCCC and became a party to the Paris Agreement. Further on the practice L. Helfer, 'Terminating Treaties', in D. Hollis (ed), The Oxford Guide to Treaties (OUP, 2012), 634.

${ }^{17}$ Sir G. Fitzmaurice, The Law and Procedure of the International Court of Justice (Cambridge, 1986), vol. I, 403-4.
} 
with the treaty beyond its currency. The State's responsibility for treaty-conforming exercise of its jurisdiction continues once it has established its responsibility for a certain situation.

This rationale is reflected in the Commentary of the UN International Law Commission (ILC), the body that drafted what was later to become Art. 70 of the Vienna Convention. This Commentary cites, approvingly and for illustration of what was meant by "legal situation", Art. XIX of the Convention on the Liability of Operators of Nuclear Ships. With respect to ships licensed during the currency of the Convention, liability for a nuclear incident is to continue after termination of that Convention for a certain period. ${ }^{18}$ The Commentary also cites Art. 58(2) of the European Convention of Human Rights which provides for the continuing responsibility after withdrawal has become effective for all acts capable of violating the Convention. The withdrawal provisions of the four Geneva Conventions ${ }^{19}$ expressly stipulate the continuing obligation in regard to legal situations created before withdrawal. If the withdrawing party is a State involved in a conflict, the withdrawal 'shall not take effect until peace has been concluded, and until after operations connected with release and repatriation of the persons protected by the present Convention have been terminated'. Treaties on cross-border movement of investment also regularly provide for a carry-over period of the protective obligations for the life-time of investments already admitted. ${ }^{20}$ The withdrawing party is obliged to continue to respect the protective standards, namely non-discrimination on grounds of nationality, and fair and equitable treatment for investments.

\section{b. Created rights of individuals}

But does Art. 70(1)(b) VCLT also continue rights of individuals created in the execution of the treaty? The wording of Art. 70 does not exclude the proposition that rights of states under a treaty can at the same time be rights of individuals. ${ }^{21}$

The objective of legal certainty and non-retroactivity of Art. 70(1)(b $)^{22}$ demands that individual rights created in the execution of a treaty continue past its end. ${ }^{23}$ That is reinforced by the elementary considerations of humanity to be respected in the interpretation and application of all international law. ${ }^{24}$ The concept of individual rights in international law has, since 1969, indeed evolved beyond the traditional acquired rights doctrine. It now recognises that multilateral law-making treaties whose primary function is to protect the individual confer individual rights directed towards other states as well as against the State of nationality. Thus, in LaGrand, the International Court of Justice

\footnotetext{
${ }^{18}$ Other environmental treaties provide similarly, see Art. 19 Espoo Convention: 'Any such withdrawal shall not affect the application of Articles 3 to 6 of this Convention to a proposed activity in respect of which a notification has been made pursuant to Art. 3(1).'

${ }^{19}$ Arts. 63/62/142/158.

${ }^{20}$ The US model bilateral investment treaty provides that investments constituted before denunciation will benefit from protection ' $f]$ ]or ten years from the date of termination'. The multilateral Energy Charter Treaty provides for twenty year, Art. 45(3)(b) ECT.

${ }^{21}$ Ascenio, note 15, paras 23/24; M. E. Villiger, Commentary on the VCLT (Brill, 2009), 865-875.

${ }^{22}$ The object and purpose of a treaty is decisive for interpretation, Art. 31(1) VCLT,

${ }^{23}$ Nollkaemper, note 13, 187.

${ }^{24}$ Constant jurisprudence of ITLOS, see "Juno Trader" (Saint Vincent and the Grenadines v. GuineaBissau), Prompt Release, Judgment, ITLOS Reports 2004, p. 17, para. 77; “Tomimaru” (Japan v. Russian Federation), Prompt Release, Judgment, ITLOS Reports 2005-2007, p. 74, para. 76; "M/V Louisa (Saint Vincent and the Grenadines v. Kingdom of Spain), Judgment, ITLOS Reports 2013, para 155.
} 
found an individual right to consular protection arising under Art. 36 of the Vienna Convention on Consular Protection for the nationals of a State party against another party. ${ }^{25}$ That individual right under the Consular Convention is interconnected with rights of the State of nationality, and any violation of the individual right at the same time entails a violation of the rights of that State. ${ }^{26}$ These rights are not affected by withdrawal. A close precedent is the treaty on Netherlands-Indonesian Union. That treaty exempted Indonesian citizens from the general requirement of a labour permit in the Netherlands. After Indonesia denounced the treaty in 1956, the Netherlands ceased to grant that exemption to Indonesian citizens, while maintaining the rights of those who were already residing. ${ }^{27}$ The strengthening of human rights treaties against withdrawal points in the same direction. Thus, the Human Rights Committee concluded that North Korea could not withdraw from the UN Covenant on the Civil and Political Rights in the absence of an explicit clause. ${ }^{28}$ Nor must state succession affect these rights. ${ }^{29}$

The Commentary of the UN International Law Commission (ILC) on "rights" in Art. 70 should not be seen as a bar for a dynamic interpretation of the clause on treaty-conferred rights in light of the practice since 1969. This Commentary affirms that the provision is not concerned with 'vested interests of individuals' ${ }^{30}$ It is often quoted to support the conclusion that individual rights are not covered by Art. 70. However, a careful examination of the drafting history of in the ILC reveals the specific and limited purpose for that comment. In fact, Sir Humphrey Waldock, as ILC special rapporteur, had earlier produced a draft Article providing that withdrawal 'shall not affect the validity of any act performed or any right acquired under the provisions of the treaty prior to its termination' ${ }^{31}$ That encountered criticism in the ILC that it included the concept of "acquired right" already controversial in national law and even more in international law. ${ }^{32}$ Waldock responded that that it had not been his intention to introduce the "concept of vested rights, in the special sense that it possessed in one branch of law", and promised a redraft to make clear that the provision covered rights "by virtue of being vested directly under the treaty, but not as a result of acts performed under the treaty regime". ${ }^{33}$ What the Article $70(1)(b)$ VCLT therefore excludes are private contractual or

\footnotetext{
${ }^{25}$ LaGrand (Germany v. United States of America), [2001] ICJ Reports 466, para. 77.

${ }^{26}$ Avena and Other Mexican Nationals (Mexico v. United States of America), [2004] ICJ Reports 4, at para 40.

${ }^{27}$ K.S. Sik, 'The Concept of Acquired Rights in International Law', (1977) 120 NILR 137-38.

${ }^{28}$ General Comment No 26, Continuity of Obligations, UN Doc CCPR/C/21/Rev. 1/Add 8/Rev. 1 (1997).

${ }^{29}$ See Opinion No 9 of the Badinter Commission in regard to the succession to the Former Yugoslavia, para 2 "The chief concern is that the solution [to the succession] should lead to an equitable outcome, ...., and more particularly, the fundamental rights of the individual, and of peoples and minorities", reprinted in D. Turk, 'Recognition of States: A Comment', (1993) 4 European Journal of International Law, 66 at 89. And China as the successor state to the UK became bound by the Covenant in regard to Hong Kong, P.M. Eisemann/M. Koskenniemi (eds), State Succession: Codification Tested against the Facts (Martinus Nijhoff, 2000).

${ }^{30}$ ILC Commentary, note 21, at p. 265, para 3.

${ }^{31}$ Revised draft art. 53(1)(b), A/CN.4/L.117 and Add.1 (emphasis added).

${ }^{32}$ ILM member Jimenez de Arechaga, Summary record of the 846th meeting, A/CN.4/SR.846, in ILC Yb 1966 vol. I(2), para 63; See Villiger, note 21, 865-875 (acquired or vested rights in international investment law).

${ }^{33}$ Sir Humphrey Waldock, Special Rapporteur, Summary record of the 846th meeting, A/CN.4/SR.848, in ILC Yb 1966 vol. I(2); para 8 (emphasis added).
} 
property rights/interests under national law. ${ }^{34}$ It does not exclude individual rights conferred directly by treaty.

\section{Van Gend en Loos, and the continuing rights of individuals under the Founding Treaties}

Ultimately, the object and purpose of the Founding Treaties determines which legal situations and rights continue after withdrawal.

Member states have created such legal situations in the execution of the Founding Treaties in objective law, by conferring nationality and hence the status of Union Citizenship, and then by admitting citizens moving from another Member State pursuant to the Treaties. The Member State then has to continuously respect the Treaties in relation to those citizens. These legal situations once created shall not be 'affected' by withdrawal. They continue per Art. 70(1)(a) of the Vienna Convention and Art. 50 TEU.

Citizenship and the related rights also create individual rights within the meaning of Art. 70(1)(b) VCLT. As the famous van Gend en Loos case makes clear, the Treaties confer rights not just on the States parties, but also on individuals. ${ }^{35}$ They confer rights on citizens having exercised their free movement rights under the Treaties, as well as those that have not yet done so, for the object and purpose of the Founding Treaties is to create the legal certainty for persons to move, long-term, to other Member States.

\section{Practice of the EU}

Continuity is also based on the relevant practice of the EU, which must inform the interpretation of Art. 50 TEU.

Already in the context of Algerian independence, the CJEU had established a general principle that pension rights which had been acquired by workers during periods of employment in a territory which has subsequently ceased to belong to the Community continue. ${ }^{36}$

In 1986, Greenland then presented the case of withdrawal from the territory of the Union as a result of a referendum in that part of the Denmark. The then European Community and Denmark concluded a treaty that provided that the Treaties no longer apply while preserving the rights of

\footnotetext{
34 "Vested interest" as defined in Blackstone's law dictionary as "possession, ownership right" is a concept of English land law. The ICJ referred to continuing property rights after the end of a treaty as customary law in Northern Cameroons, [1963] ICJ Reports 34. Earlier Certain German interests in Polish Upper Silesia, Germany v Poland, (1926) PCIJ Series A No 7, 42. Further P. Lalive, 'The Doctrine of Acquired Rights', 145, 162, discussing acquired rights in private and public international law with reference to state practice.

${ }^{35}$ Case 26/62, [1963] ECR 2, 12.

${ }^{36}$ In Case C-6/75, Horst v Bundesknappschaft, The ECJ found Regulation 109/65/EEC had retroactively deleted the reference to Algeria but explicitly excepted any acquired rights of individuals. AG Reischl had referred to ILO Convention (No 48) concerning the Establishment of an International Scheme for the Maintenance of Rights under Invalidity, Old-Age and Widows' and Orphans' Insurance, 22 June 1935, entered into force 10 August 1938, that also protects pension rights acquired by migrant workers in a host state.
} 
Union citizens already resident in Greenland. ${ }^{37}$ The explanatory memorandum of the Commission makes explicit that those Treaty-derived individual rights ought to be protected in the same manner as acquired pension rights. ${ }^{38}$

The Greenland Treaty entered into force on 1 February 1985. It provides that the Treaty establishing the European Community (EC Treaty) shall no longer apply to Greenland, but that Greenland shall be associated to the European Community as one of the overseas countries and territories (OCTs). ${ }^{39}$ The detailed status of Greenland is set forth in the attached protocol to the Treaty. Art. 2 of the Protocol contains the principle that the rights of Union citizens in the withdrawing territory of Greenland shall be preserved, and it empowers the Commission to make proposals to the Council to that effect. ${ }^{40}$ The EU-Greenland comprehensive partnership is now based on Council Decision 2014/137/EU. ${ }^{41}$

On the other hand, the EU has been prepared to extend EU citizenship to persons other than residents of the EU itself. Examples drawn from UK experience are those of the residents of the Crown Dependencies, who are included within the definition of British citizens, and hence qualify as EU citizens, even though they do not reside in territories which are constitutionally part of the EU.

\section{Constitutional law and practice of the Member States}

Constitutional law and practice also demonstrates the human right quality of citizenship and its continuity in instances of territorial changes. In what follows, precedents in British and German constitutional practice will be discussed.

\section{British constitutional law and practice}

UK citizenship law was at one time notorious for its complexity, reflecting the fundamental changes that took place, over the 20th century, in the relationship between the UK and the various territories which were formerly part of the British Empire. However, in recent years the position has become simpler and, for the purpose of the present Report consideration can be confined to the two main surviving categories, namely - British citizenship and British Overseas Territories citizenship together with the closely related statuses of Irish citizenship and Commonwealth citizenship.

British citizenship is defined by the British Nationality Act 1981 and is basically enjoyed by those born in the UK and others who enjoy it or acquire it by descent, registration or naturalisation. For this purpose the UK is defined so as to include not only the UK proper but also "the Islands", i.e. the three quasi-independent Crown Dependencies - the Bailiwicks of Jersey and Guernsey (the Channel Islands) and the Isle of Man.

British Overseas Territories citizenship ("BOTC") is also defined by the British Nationality Act 1981 and, as in the case of British citizenship, is acquired at birth by those born in a British Overseas

${ }^{37}$ Treaty amending, with regard to Greenland, the Treaties establishing the European Communities, [1985] OJL 29/1, Protocol on special arrangements, Art. 2.

${ }^{38}$ Commission, Opinion, Status of Greenland, 2 February 1983, EC Bulletin, Supplement 1/83, p. 21.

${ }^{39}$ Art. 3 of the Greenland Treaty added Art. 136a.

${ }^{40}$ Art. 2 reads "The Commission shall make proposals, ..., for the maintenance of rights acquired by legal and natural persons during the period that Greenland was part of the Community".

Greenlanders retained the right to a Danish passport and the ensuing rights under the Treaties.

${ }^{41}$ Council Decision 2014/137/EU of 14 March 2014 on relations between the European Union on the one hand, and Greenland and the Kingdom of Denmark on the other, [2014] OJ L 76/1. 
Territory and can also be acquired by descent, registration or naturalisation. British Overseas Territories include territories such as Bermuda and the Falklands Islands. Significantly, for the present discussion, they include Gibraltar. BOTCs do not automatically have the right to enter and to reside in the UK although if they qualify for that right they enjoy, within the UK, the same citizenship rights as British citizens. However, those who were BOTCs prior to the 21 May 2002 automatically became British citizens under the British Overseas Territories Act 2002 and others may, almost without exception, unconditionally acquire the status of British citizens by registration. The significance of this category of UK citizenship is therefore nowadays limited.

UK citizenship law has adopted pragmatism and flexibility in order to respond to situations under which political and constitutional changes would otherwise have resulted in groups of individuals being deprived of rights which they had previously enjoyed.

British citizens are, as long as the UK remains a member of the EU, EU citizens. This applies not only to British citizens who reside in the UK proper or have a connection with a British Overseas Territory, but also to residents of the Isle of Man and the Channel Islands, even though those territories are not part of the EU. The special status of Gibraltar in relation to the $\mathrm{EU}^{42}$ means that the provisions of the Treaties apply there generally. Its residents are, by virtue of being UK citizens, EU citizens. Although they are not represented in the UK Parliament they are represented in the European Parliament as part of the South West England and Gibraltar UK constituency. Commonwealth citizens (other than British citizens and BOTCS) are not EU citizens unless they are citizens of the Commonwealth states which are members of the EU - Malta and Cyprus.

Specifically, the UK has accorded to Irish citizens and to the citizens of Commonwealth countries rights equivalent to those of UK citizens. Had it not been for these provisions, persons who had previously enjoyed the status equivalent to the modern status of British citizens, i.e were British subjects prior to the enactment of the British Nationality Act 1948, would have lost those rights. In the case of Irish citizens the continuing rights enjoyed extend to full freedom of movement to and from the UK and a right of abode there. In the case of Commonwealth citizens they no longer enjoy the full freedom of movement previously enjoyed by British subjects but once settled in the UK they enjoy effectively full rights of citizenship. UK practice therefore demonstrates that, given the political will, flexible and pragmatic solutions can be found, in accordance with existing UK constitutional precedent, for arrangements which preserve the rights of individuals and of classes of individuals associated with territories whose relationship with the UK has changed.

Historically, the equivalent status to that of citizenship under the law of the then British Empire (including self-governing territories such as Canada, Australia, New Zealand and South Africa) was that of "British subject", that is a person who owed allegiance to the Crown and who was entitled to its protection. In principle, this status entitled the holder to travel and reside freely anywhere within the Empire. In practice, the vast majority of British subjects, which included hundreds of millions of residents of colonial territories in Africa and Asia, had neither the means nor the inclination to exercise this theoretical freedom of movement.

The impetus for creating a more restricted status of British citizen came from the recognition ${ }^{43}$ that the most constitutionally advanced of the former colonies had become sovereign states who wished

\footnotetext{
${ }^{42}$ Art. 355(3) TFEU.

${ }^{43}$ Formalised in the UK Statute of Westminster 1931.
} 
to enact their own citizenship laws. The states in question (which by then also included India, Pakistan and Sri Lanka) agreed, in 1947, that they would all legislate so as to establish their own citizenship laws. The British Nationality Act 1948 gave effect to this principle in the UK. It created the status of Citizen of the United Kingdom and Colonies, whilst retaining the status of "British subject" (which could also be known by the alternative term of "Commonwealth citizen") for, primarily, citizens of the independent former colonial territories. In relation to the UK, immigration by Commonwealth citizens was unrestricted and they enjoyed the same rights within the UK as did UK citizens.

Special provision was, however, needed in relation to Ireland. The whole of Ireland was, until the establishment of the Irish Free State in 1922, part of the UK and those born in Ireland enjoyed full rights as British subjects. Constitutionally, the Irish Free State was, under UK law, a British Dominion, with a similar status to that of Canada, Australia, New Zealand and South Africa. Those born in the Irish Free State therefore continued to be treated, by the UK, as British subjects. The Irish Free State's constitution, on the other hand, created the status of Irish citizen, which UK law regarded as having only local effect within Ireland and being parallel to the status of British subject and not one that displaced that status ${ }^{44}$. The Irish Free State (and its successor, the Irish Republic) extended the right to Irish citizenship to those born in Northern Ireland if they chose to assert it.

The British Nationality Act 1948 made special provision for the Irish Republic ("Eire"), which did not wish its citizens to retain the status of British subjects (or Commonwealth citizens). The then UK Prime Minister, Mr Attlee, set out the British Government's policy on the status of Irish citizens in the UK in a statement to the House of Commons on 25 November $1948 .{ }^{45}$

"The Eire Government have stated that they recognise the existence of a specially close relationship between Eire and the Commonwealth countries and desire that this relationship should be maintained. These close relations arise from ties of kinship and from traditional and long-established economic, social and trade connections based on common interest. The United Kingdom Government, for their part, also recognise the existence of these factual ties, and are at one with the Eire Government in desiring that close and friendly relations should continue and be strengthened.

Accordingly the United Kingdom Government will not regard the enactment of (the Republic of Ireland Bill) by Eire as placing Eire in the category of foreign countries or Eire citizens in the category of foreigners."

The status of Irish citizens resident in the UK was finally fixed by the Ireland Act 1949. Under that Act there was full recognition by the UK of complete political separation between the UK and the Irish Republic. But the factors referred to by Mr Attlee, together with the high level of immigration into the UK from Ireland which had taken place over the years, both before and after the creation of a distinct Irish citizenship, together with the position of the many residents of Northern Ireland who had opted for Irish citizenship, resulted in a pragmatic provision enacted in section 2 of the 1949 Act. It was recognised that the Republic of Ireland was not (and is not) to be regarded as a foreign country for the purposes of UK legislation. So Irish citizens were not to be regarded as aliens but neither were they Citizens of the UK nor Commonwealth citizens. Those born, before 1922, in that

\footnotetext{
${ }^{44}$ Murray v Parkes [1942] 2 K.B. 123.

${ }^{45}$ HC Debates 25 November 1948, volume 458 column 1414.
} 
part of Ireland which passed under the jurisdiction of the Irish Republic and who had not resided there throughout the intervening period were enabled to retain UK citizenship and Irish citizens resident in the UK could acquire UK citizenship by registration. But Irish citizens who resided in the UK, whilst remaining Irish citizens, were permitted to enjoy all the benefits of UK citizenship, ${ }^{46}$ including absolute freedom to take up residence and employment in the UK and to play a full part in political life, including voting in parliamentary elections and even seeking membership of the national legislature, a state of affairs that will not be affected by the UK leaving the EU. ${ }^{47}$

The same is true of those Commonwealth citizens who are granted the right of abode in the UK. As a result of the increasing numbers of Commonwealth citizens who exercised their right to settle in the UK after the Second World War legislation was eventually enacted to subject them to immigration controls, beginning with the Commonwealth Immigrants Act 1962. Commonwealth citizens have no general right of abode in the UK. Once settled in the UK they do, however, enjoy effectively the same rights as those of UK citizens.

\section{German constitutional law and practice}

Germany provides another precedent of continuing citizenship despite territorial changes. The then "West Germany", the Federal Republic of Germany considered itself the continuer of the German state. The former German Democratic Republic, "East Germany", was considered to be in a state of incomplete secession. West Germany treated East Germans as its citizens, under the continuing German citizenship law. That citizenship could also be passed on to descendants. ${ }^{48}$ West Germany justified that position with regard to fundamental rights, and also the right to self-determination of the entire German people to decide on their State, which the East Germans were being denied.

\section{Providing legal certainty}

In its constant case law, the Court has emphasised that Union Citizenship is linked with the general principles of the Union legal order, and, chief among these, legal certainty. Individuals must know their rights to be able to plan ahead. ${ }^{49}$ This legal certainty becomes a paramount requirement, for the Union, in protecting Citizens' rights post-Brexit. Action of the EU (and the UK) is required to clarify the situation of citizens when that time is reached, in a legally certain manner, and ensure that rights are enforceable.

This requirement of providing legal certainty in instances of withdrawal from treaty also underlies international law. Art. 70(1)(b) of the Convention does not explicitly obligate the parties to enter into a further treaty clarifying the consequences of a withdrawal. However, the (second) report of the first Special Rapporteur of the ILC, Sir Gerald Fitzmaurice, on the draft Articles that were to

\footnotetext{
${ }^{46}$ Described by the UK Government as "an exchange of citizenship rights" rather than common citizenship (HL Debates 15 December 1948 volume 159 column 1101).

${ }^{47} \mathrm{~A}$ high degree of reciprocity exists as between the UK and the Republic of Ireland, with the latter permitting UK citizens to reside and work in Ireland without restriction, to enjoy health and social security benefits on the same terms as Irish citizens and even to vote in elections to the Irish legislature.

${ }^{48}$ Federal Constitutional Court of Germany, Teso, 21 October 1987, BVerfGE 77, 137.

${ }^{49}$ Case C-67/14, Alimanovic, 15 September 2015 (legal certainty for the case that the grounds on which individuals had originally exercised their free movement rights and on which their residence was originally based no longer apply).
} 
become the Vienna Convention, considered it an implicit obligation in order to avoid intolerable legal uncertainty to conclude a treaty on the terms of withdrawal. ${ }^{50} \mathrm{Art} .70(1)(\mathrm{b}) \mathrm{VCLT}$ therefore determines parameters for the arrangements must feature in such a treaty: rules that render legally certain the legal situations and rights for the time post withdrawal. Art. 50(2)(2) TEU turns that into an explicit obligation for the EU and the UK.

The CJEU has constantly held that that legislation concretises the primary Citizenship law. In that way it provides the citizen with legal certainty. It is on these bases that citizens originally exercised their free movement right and continue to exercise these. Legal certainty on these two grounds makes the existing legislation, namely the Citizenship Directive and Regulation 492/2011 on freedom of workers within the Union, the minimum standard for the future. The object and purpose of this legislation has been to concretise the Founding Treaties so as to create legal certainty for persons to plan and move, long-term, to other Member States.

\section{B. Creating a new status and relating rights: Associate Union Citizenship}

There is, however, an opposing reading of European Union law that Union Citizenship, whilst being an individual status, remains closely tied to the collective contribution of a Member State's population to the European project. Under this premise, the exit of a Member State from the Founding Treaties will affect the Union Citizenship of its nationals. That corresponds to the clause in Art. 70(1)(b) of the Vienna Convention that a "treaty may provide otherwise or the parties may agree otherwise". In other words, the treaty may provide that "legal situations" and "rights" do not continue after its end. In that reading, Art. 50 TEU could be understood as providing that Union Citizenship and the related rights do not continue after the withdrawal of a State from the Founding Treaties.

If one were to adopt that reading, then a separate status has to be created for British nationals, as nationals of a former but not current Member State, which this report discusses as an alternative model to Continuity. In this second case, the status that emerges as Associate Union Citizenship and the bundle of rights that go with it will have to be defined. EU action would, therefore, have constitutive effect.

This status will preserve the essence of the formerly held status of Union Citizenship. However, it will be exclusively personal. To that status would relate most if not all of the bundle of citizenship rights. Associate Union Citizenship will thus differ from Union Citizenship in status - it will be grounded in secondary law although enshrining it in the Treaties remains an option - and in the rights which relate to it, although to what extent is a political question. It would also be static, and would not share the dynamic quality of EU citizenship which may evolve as a result of case law and new legislation. It is true that Citizenship in the conception of the Treaty has a strong equality dimension. However, that inequality of status will be the result of objective grounds having to do with the very construction of Union Citizenship being linked with Union membership of the State of nationality.

Creating such an Associate Union Citizenship status for the post-Brexit time is not a discretionary matter. In fact, the EU has positive obligations under the Founding Treaties and the Charter of

\footnotetext{
${ }^{50}$ Doc A/CN.4/107 (ILC Yearbook 1957, vol. II), p 35, para. 6: in the absence of a clause in the treaty on the subject, questions raised by termination 'must be the subject of a separate agreement between the parties' (emphasis added).
} 
Fundamental Rights to protect the Citizenship rights of citizens of British nationality. The Union is the primary addressee of the Charter rights, Art. 51(1) of the Charter. It must not just respect these rights itself, but it must also protect the rights from interference by third States. ${ }^{51}$ That includes the fundamental Citizens' rights now guaranteed in the Charter. ${ }^{52}$ This corresponds to the general principles of international human rights law, which include the duty to respect, protect and fulfil human rights.

Brexit is an interference with the fundamental Citizens' rights. Termination of the Union Citizenship of British nationals would be the immediate consequence of the decision of the UK to withdraw from the European Union. In regard to that interference, the Union is bound to take proportionate protective measures, both internally and externally. That protective obligation is reinforced by Art. 1 of the Charter, which provides that the Union must respect and protect human dignity, and therefore its manifestations, the fundamental rights of citizens.

Not taking protective measure would create a limitation on those rights attributable to the Union. In the discharge of this protective obligation, proportionate measures have to be taken to protect the exercise of these rights after Brexit. That obligation to take positive protective measures extends to Union Citizenship of those of British nationality post-Brexit. These measures would be declaratory for Continuity; for the Associate Union Citizenship, they would be constitutive.

\section{Union legislation to preserve Union Citizenship}

Legislation is the means the Union has to ensure Union Citizenship rights for British nationals post Brexit (I). The available competences empower the Union to legislate to that effect (II). Critically, however, such legislation will be limited to the territory of the Union and not be able to bind the UK. Equal treatment of all Union citizens demands to include equivalent protection for Union citizens of EU-27 nationality in the Withdrawal Agreement between the EU and the UK (III).

\section{Structure of the legislation}

Such legislation will only have a clarificatory role in the case of Continuity as a matter of logic. This legislation to continue citizenship would essentially extend the law as laid down in Directive 2004/38 and Regulation 492/2011, and would also codify the rights that are recognised in the case law of the CJEU. It would protect the rights of permanent residents and, for a defined period of time, the legitimate expectation of others to obtain that status. It could also protect dormant rights for a defined period of time.

By setting these time-limits, the legislator would be bound to respect the principle of proportionality, both by virtue of Art. 20 TFEU and by virtue of Art. 52(1) of the Charter of Fundamental Rights.

\footnotetext{
51 In Case C-362/14, Schrems, 6 October 2015, the Court articulated the protective obligation in regard to passenger data of Union citizens to be transmitted, on the basis of a treaty, to the USA. ${ }^{52}$ In Spain v UK, the Court reinforced the European Court of Human Right's judgment in Matthews, where that Court stated that States were under the obligation to take positive measures to ensure that elections to the EP were held in their territory but also all dependent territories. This obligation to take positive measures also falls on the EU itself. This ECHR standard now forms the minimum standard of Art. 39 CFR, pursuant to Art. 52(3) CFR).
} 


\section{Competences for the legislation}

Legislating on Union Citizenship must be compatible with the constitutional principle of conferred and thus limited competences of the European Union, Art. 5(1) TEU. There is no single competence title for the defining the rights of citizens. In particular, Art. 20(2) TFEU is a not a comprehensive competence. However, Arts. 21(2), 22(2), 23(2) and 24(2) TFEU provide the requisite competences for the Union legislature. The wording of these provisions covers rule-making to preserve the rights of citizens for the time after the withdrawal of their Member State. Furthermore, these competences ought to be interpreted to cover such rule-making though which the Union legislator provides legal certainty and protects the fundamental rights of citizens post-Brexit. While it is true that the Charter does not confer new competences on the Union beyond those in the Treaties, the judgment in Chavez demonstrates that the Charter's fundamental rights do have an impact on the interpretation of the scope of primary Union Citizenship law.

\section{Free movement, Art. 21(2) TFEU}

Art. 21 and Art. 46 TFEU are the competences for the Union to legislate on the continuing free movement and employment of citizens. The competence for preserving residence rights of all citizens, including non-economically active persons, is Art. 21(2). Art. 46 is the competence to legislate specifically for workers.

\section{Right to vote and stand, Art. 22(2)}

Art. 22(2) and Art. 223(1)(2) TFEU serve as the legal basis to legislate on the continuing right to vote and to stand for the EP. The current legislative provision could be amended to clarify the exercise of these rights. A Decision of the European Council sets forth general principles for the Member States in organising the elections to the Parliament. ${ }^{53}$ As the law is currently not fully harmonised, the Member States must provide for the details, a competence they must exercise in accordance with Art. 39 and the other rights of the Charter of Fundamental Rights as well as Art. 18 TFEU. These standards prevent the remaining Member States from discriminating against British nationals on the basis of their nationality.

\section{Primary law Citizenship rights}

The CJEU has constantly emphasized that the secondary legislation does not exhaust the rights of citizens. ${ }^{54}$ Protecting these primary law rights through legislation is a matter of legal certainty. The discussed competences provide the legal basis. The Court has shown, not least through analogous application, that the Citizenship Directive can become co-extensive with the primary law. ${ }^{55}$ This will be further discussed in Part III of this report.

\footnotetext{
${ }^{54}$ Further rights flow from the Treaties directly: (1) the primary residence and free movement rights directed towards the home state of the citizen; (2) The primary right to vote and to stand, which any Union citizen can exercise in its home Member State. (3) The primary, albeit derived movement right of TCN family members that are carers of a Union citizens, and rights to work of TCN family members.

${ }^{55}$ Opinion of AG Y. Bot in Case C-165/16, Lounes.
} 


\section{Legislative procedure}

The procedure is the ordinary legislative procedure. The Commission can be invited to submit a proposal by a citizens' initiative, Art. 11(4) TEU. The procedures and conditions for the citizens' initiative are set out in the Regulation on the citizens' initiative. ${ }^{56}$ The Commission's proposal then will require approval by the European Parliament deciding by simple majority, and by the Council deciding by qualified majority.

\section{Ensuring equal treatment of all Union citizens}

The legislation referred to in the previous section would protect British nationals in the EU. It would not, however, have any binding effect in the UK post-Brexit.

There is indeed a need for the Union legislator to ensure equal or at least equivalent protection of Union citizens of EU-27 with that of continuity citizens of British nationality. Equal treatment is a general principle of Union law, and it is now a fundamental right, Art. 20 CFR, binding on the Union. It requires that all Union citizens placed in the same situation are treated in the same way, unless there are objective reasons that would justify a differentiation.

The citizens placed in the same situation are those affected by the withdrawal of the UK from the Founding Treaties. These are British nationals on the territory of the Union, on the one hand, and EU-27 nationals on UK territory, on the other. Both groups will be affected in the continuous enjoyment of their rights. However, legislation could only preserve the rights of British nationals on the Union territory, but not on the territory of the UK. While Continuity does not change anything, the best way to protect and make those rights of EU-27 nationals enforceable is to include them in the Withdrawal Agreement.

\section{Is legislating on the Citizenship of British nationals compatible with international law?}

This envisaged Union legislation must also be compatible international law, ${ }^{57}$ and in particular the customary international law on citizenship. ${ }^{58}$ It must not intervene into the internal affairs of the UK. Under international law, the State (or international organisation) extending its citizenship to nationals of another State needs to have a legitimate link with those individuals. Such a link is created by the fundamental right to citizenship, as well as the self-determination of a people. States have indeed extended their citizenship to the persons holding the citizenship of another State as well as to their descendants, on both these grounds.

The envisaged Union legislation thus does not intervene in the internal affairs of UK. Protecting the existing fundamental rights of citizenship from loss against their will constitutes of the legitimate link.

\footnotetext{
${ }^{56}$ Regulation (EU) No 211/2011 of the European Parliament and of the Council of 16 February 2011 on the citizens' initiative, [2011] OJ L 65/1), consolidated version 01/07/2014.

${ }^{57}$ Both treaties and international customary law rank above and are justiciable yardsticks for legislation, Racke, paras 45 and 46, and Joined Cases C-402/05 P and C-415/05 Kadi and Al Barakaat International Foundation v Council and Commission [2008] ECR I-6351, para 291.

${ }^{58}$ Case C-364/10, Hungary v Slovakia, 16 October 2012.
} 


\section{The negotiated process of exiting the Founding Treaties}

Such legislation would also not interfere with the institutional competences of the Council and the Commission to negotiate and conclude the agreement on the arrangements for the UK's withdrawal..$^{59}$ The European Parliament has the constitutional role to act as guardian of individual rights against all infringements. It assumes the protective responsibility that parliaments in all liberal democracies now have. Within the constitutional architecture of the Union, this function of the Parliament comprises its role in the negotiations on a Withdrawal Agreement, but it also comprises the Parliament unilaterally providing protection by legislation, as a means of last resort should negotiations not produce an adequate result.

\section{The Withdrawal Agreement between the EU and the UK on Associate Citizenship}

The alternative to legislation by the Union is a treaty between the EU and the UK, binding on both at the time withdrawal takes effect. That treaty will be capable of preserving the rights of Union Citizens, as well as conferring the new status of Associate Citizenship on them. The substantive content of the treaty would be based on reciprocity (I). It would align rights of British nationals in the Union with rights of EU-27 Union citizens in the UK, who would effectively become associate British nationals under British law. The treaty could also ensure judicial protection of such rights (II). In Art. 50(2) TEU, the Union has a competence to conclude a 'Withdrawal Agreement' with the exiting State (III). The Union is exclusively competent to conclude such a treaty, but if the treaty provided for any amendment of the Founding Treaties, that would turn it into a so-called mixed agreement in need of ratification by all remaining Member States.

\section{Architecture of the Withdrawal Agreement: substance}

The architecture of the Withdrawal Agreement has to respect reciprocity of rights and obligations of the parties. That results in a two-pillared architecture.

\section{Associate Union Citizenship and related rights of British nationals} The first pillar concerns British nationals in the Union post-Brexit. Either their Union Citizenship will be preserved or an Associate Union Citizenship will be created with most if not all citizenship rights. The practical differences between these options might prove small.

Importantly, the rules provided in the agreement on timeframes must be proportionate.

This is so for citizens free movement rights already exercised. Thus, this includes the rights of persons who, under the Treaties, have moved to another Member State and are still residing there by the time withdrawal becomes effective. There are then at least two main categories of such exercised rights, plus frontier workers. First, there are citizens having acquired the right of permanent residence, after five years of having exercised a right to reside under the Citizenship Directive 38/2004 (CRD). Permanent residence, a major innovation of the Directive, was clearly intended to provide individuals with legal certainty that residence would no longer be subject to conditions and could not be terminated except for the narrow preconditions of Arts. 27 and 28 CRD. Citizens residing lawfully but who will not yet have achieved permanent residence carry with them the protected legitimate expectation of obtaining permanent residence, under the sole condition

${ }^{59}$ Art. 50(2)(3) TEU, Art. 218 TFEU. 
that he/she fulfils the conditions for a right to residence for five years. Dormant citizenship rights, that is to the rights of citizens to move to a remaining Member State after Brexit will have to be protected for a period of time, but the EU and the UK have a considerable margin of discretion in that regard.

The political right to vote and stand is accessory to the exercise of the right to move. The exercise of this rights in the host Member State and must be protected. But the right to vote in the home Member State presupposes EU membership of that home state. It cannot be protected in the case of a withdrawing state. The right to consular representation does not need exercise of free movement, but its protection in in the case of a withdrawing State is subject to constraints arising in international law.

\section{Associate British Citizenship and related rights of EU-27 nationals}

The second pillar concerns EU-27 nationals in the UK post Brexit. This means that Associate British Citizenship comes with a bundle of rights equivalent to those of Union citizens, but enshrined in national law. These rights will retain a distance from the rights of full British citizens, in particular regarding the franchise for general elections.

\section{Architecture of the Withdrawal Agreement: judicial protection}

Art. 47 of the Charter of Rights demands that these rights be judicially protected. That protective guarantee extends to all rights guaranteed by the law of the Union, including international law binding on the Union, and thus the Withdrawal Agreement. The bearer of the rights must have access to an independent court or tribunal with the requisite remedies. That court or tribunal need not necessarily be established in one of the Member States, though.

\section{Two judicial pillars}

There will be two separate judicial pillars. The rights of associate citizens will be exercised in the territory of the Union and therefore be invoked before the national courts of the Member States. By contrast, the rights of $A B C$ will be enshrined in British law and exercised in the UK. They can only be invoked before the British courts.

\section{Jurisdiction of the CJEU}

Judicial protection within this two-pillar judicial architecture would be reinforced if the European Court of Justice also had jurisdiction to give rulings on the interpretation of the Withdrawal Agreement also in so far as it concerned the UK. EU-27 courts will then be in the position to refer preliminary questions as to interpretation and validity of the agreement to the ECJ, under Art. 267 TFEU. In principle, the CJEU does not have jurisdiction in a third State, which the UK will be postBrexit. Yet, a treaty may confer on it jurisdiction outside the EU territory. ${ }^{60} \mathrm{~A}$ joint committee of the

${ }^{60}$ Opinion 2/91. 
parties to the Withdrawal Agreement, each party, ${ }^{61}$ or indeed the British courts ${ }^{62}$ could be empowered (but not obliged) to refer questions to the CJEU. However, the design by treaty of such jurisdiction outside of the EU must not change the essential character of the CJEU. ${ }^{63}$ The CJEU must therefore be able to issue binding rulings, and not just advisory opinions.

\section{A dedicated judicial or arbitral mechanism}

The alternative is to establish a dedicated judicial or arbitral mechanism for the Withdrawal Agreement. Such a court or arbitral tribunal would have jurisdiction over the agreement both in regard to the EU and the UK.

The European Union may establish dedicated international courts or tribunals that have the power to issue binding decisions for the Union ${ }^{64}$ However, the interpretation of EU law must remain the exclusive competence of the ECJ. That competence must be guaranteed in a legally binding form, either in the treaty itself or in a protocol. ${ }^{65}$

\section{The competence of the Union for a Withdrawal Agreement with the UK}

Art. 50(2) TEU confers on the EU the competence to conclude a treaty "on arrangements for withdrawal" with the UK. This competence comprises making rules to preserving existing citizenship rights of individuals, but not the competence to agree on the "(framework of the) future relations".

The competence of Art. 50(2) TEU is exclusive, precluding the remaining Member States from entering into any individual treaty with the UK. It is true that Art. 3(1) TFEU does not include Art. 50 TEU in its list of exclusive competences of the Union. But Art. 50 TEU is an implied exclusive competence within the meaning of Art. 3(2) TFEU, if the conclusion of the agreement "may affect

\footnotetext{
${ }^{61}$ A Protocol to the EEA Agreement provides: "If a dispute concerns the interpretation of provisions of this Agreement, which are identical in substance to corresponding rules of the Treaty establishing the European Economic Community and the Treaty establishing the European Coal and Steel Community and to acts adopted in application of these two Treaties and if the dispute has not been settled within three months after it has been brought before the EEA Joint Committee, the Contracting Parties to the dispute may agree to request the Court of Justice of the European Communities to give a ruling on the interpretation of the relevant rules". The European Common Aviation Area Agreement allows the parties to seize the CJEU. Art. 20(3) reads: "If the Joint Committee after four months from the date when the matter was brought before it has not succeeded to take a decision resolving the dispute, the parties to the dispute may refer it to the Court of Justice whose decision shall be final and binding. The modalities according to which such referrals may be made to the Court of Justice are set out in Annex IV." The emphasis has been added.

${ }^{62}$ Under Protocol 34 to the EEA Agreement, EFTA States may permit their courts to request that the ECJ decide on a question of interpretation of provisions of the EEA Agreement which are identical in substance to provisions of the Founding Treaties, or of acts adopted pursuant to these treaties.

63 Opinion 1/00.

${ }^{64}$ ECHR Opinion. Protocol 33 to the EEA Agreement envisages arbitration procedures in certain cases.

${ }^{65}$ ECHR Opinion.
} 
common rules or alter their scope" ${ }^{66}$ The Withdrawal Agreement preserving Union Citizenship of British nationals and the related rights clearly meets this condition.

By contrast, Art. 50(2) TEU is not a competence for the Union to make any amendments to the Founding Treaties. Rather, amending the Treaties is the exclusive competence of the Member States. The Withdrawal Agreement may contain provision to amend the Treaties. ${ }^{67}$ But that would make it a 'mixed agreement' requiring for entry into force the ratification of all Member States as well as of the Union. The Union could, however, decide to provisionally apply the agreement for the duration of that ratification process.

This procedure has been followed in the closest precedent for the present case, the withdrawal of the territory of Greenland from the Treaties, including the then EEC Treaty. There, Denmark, representing Greenland internationally, submitted to the Council a proposal for revision of the Treaties, as well as introducing new arrangements for the relation between the then EEC and Greenland. The Member States then concluded a treaty with Denmark that amended the Founding Treaties. This treaty included a protocol setting out the relations with Greenland. ${ }^{68}$

\section{E. A need for Treaty revision?}

In what follows, it will be argued that the Treaty provisions on Union Citizenship do not prevent the Union from either preserving Union Citizenship or creating Associate Union Citizenship for British nationals, by way of legislation or treaty. For these statuses and the related bundles of rights can be held by individuals who will have the nationality of a non-Member State by the time the UK leaves the European Union.

\section{Art. 20(1)(2) TFEU - Union Citizenship derived from the nationality of a Member State}

Art. 20(1)(2) TFEU provides that Union Citizenship is held by individuals that have the nationality of a EU Member State. Yet Art. 20(1)(2) TFEU does not stand in the way of individuals who, at that point, will be nationals of a former but not current Member State, holding either Union Citizenship or Associate Union Citizenship and the related rights.

\section{Continued Union Citizenship}

Art. 20(1)(2) TFEU is a competence allocation: the Member States retain the competence to decide on their nationality, and, thereby, on Union Citizenship, within certain limits. That competence will not be interfered with here.

\footnotetext{
${ }^{66}$ Art. 3(2), third ground, TFEU.

${ }^{67}$ Under Art. 39 Vienna Convention on the Law of Treaties, the states parties to a treaty may amend a treaty through any additional treaty on the same subject.

${ }^{68}$ It reads: "The Commission shall make proposals to the Council, which shall act by a qualified majority, for the transitional measures which it considers necessary, with regard to the maintenance of rights acquired by natural or legal persons during the period when Greenland was part of the Community and the regularization of the situation with regard to the financial assistance granted by the Community to Greenland during that period."
} 
Preserving Union Citizenship does not affect or diminish this competence of the Member State. Union Citizenship can still only be acquired through the nationality legislation of a Member State. For Union Citizenship will not be conferred, originally, by Union legislation or treaty. Rather, it will continue as derived from that initial conferral by legislation of a (former) Member State.

Nevertheless, while preserving Union Citizenship does not extend the circle of persons entitled to Union Citizenship, it will create a direct link between the Union and the citizen, not mediated by nationality of a current Member State. That creates an individual loyalty towards the Union, which is, however, the necessary and limited consequence of the fundamental right quality of Union Citizenship.

\section{Associate Union Citizenship}

Art. 20(1)(2) TFEU does also not stand in the way of Associate Union Citizenship. Nothing in Art. 20(1)(2) TFEU indicates that Union Citizenship excludes creating another status of personal attachment to the Union. Being distinct from Union Citizenship, it cannot affect the competence of the Member State to determine the circle of Union citizens through their legislation. Associate Union Citizenship will also retain a sufficiently close connection to the construct of derived citizenship. For only nationals of a State that was a Member State of the Union will receive it.

British nationals resident in the Union territory will continue to be subject to the jurisdiction of the Union within its competences. That justifies creating a status for them akin to Union Citizenship. However, the status of an Associate Union Citizenship implies a material distance from Union Citizenship, expressed in the bundles of rights relating to Associate Union Citizenship and to Union Citizenship respectively. There are, however, already inherent limitations on Associate Union Citizenship rights which ensure a qualitative difference between the two. Thus, British nationals will not be able to exercise certain rights in their home state. They will not be able to vote or stand for the EP in the UK. Another example is the right to diplomatic representation in third States by another EU Member State than the State of nationality. While important, this is a right that depends on the solidarity and trust between the Member States, a constructive principle of the European Union as the ECJ has highlighted. ${ }^{69}$ It would also require striking new international law arrangements with the third States, overcoming the principle that states may only not represent their nationals.

\section{Art. 20(1)(3) TFEU - Additionality to national citizenship}

Nor does Continuity of Union Citizenship or Associate Union Citizenship violate the requirement of Art. 20(1)(3) TFEU that "citizenship of the Union shall be additional to and not replace national citizenship". Union law will not confer rights that exclusively national citizenship confers, such as the franchise for general elections and unconditional and unlimited residence on the national territory.

\section{Do the several Citizenship rights stand in the way?}

The Treaty also does not stand in the way of conferring the specific citizenship rights on persons who will be Third-Country nationals (TCNs). The Treaty guarantees these rights to Union Citizens that are nationals of a current Member State, but it does not exclude conferring them on TCNs.

${ }^{69}$ ECHR Opinion. 
Art. 21(1) TEU does not reserve the right to reside in the Union to Union citizens. In fact, Art. 45(2) Charter of Fundamental Rights recognises that the Union may confer free movement and residence rights on TCNs legally resident in the territory of a Member State, both economically active and nonactive.

Such residence rights could be granted under Art. 50 TEU, the lex specialis, as part of the Withdrawal Agreement. They have already been granted to Third-Country nationals by way of treaty concluded by the Union under Art. 217 TFEU. Thus, under the EEA Agreement, nationals of the third country parties - Liechtenstein, Norway and Iceland - have the rights of free movement within the Union. The EEA Agreement incorporates the Citizenship Directive 2004/38. ${ }^{70}$ The declaration lodged on that occasion underlines that there is no citizenship concept under the EEA for EEA nationals. The Directive entered into force in the EEA on 1 March 2009. Four EFTA cases consider the Directive to date. ${ }^{71}$ In Jabbi the Court found that, in conformity with the principle of homogeneity, the rights of EEA nationals are co-extensive with those of Union citizens and that non-economically active persons were included in the scope of the incorporated Directive. The Turkey Association Agreement also confers work and residence rights on the Union territory on TCNs. ${ }^{72}$

That is also case for the right to vote and stand for the European Parliament. Union Citizens are guaranteed, in primary law, the right to vote. But Art. 22 TFEU, Art. 14 TEU, and Art. 223 TFEU do not stand in the way of conferring the rights to vote and stand on TCNs by legislation or treaty. This is particularly true for the constitutional function of Parliament. Art. 14(1) TEU, reformed by the Lisbon Treaty, now provides that the Parliament represents the citizens of the Union, rather than the peoples of the Member States. The provision therefore recognises that the circle of individuals to be represented is an autonomous question that only the EU itself can determine. It may determine that this circle comprises all individuals residing on the Union territory and therefore subject to Union jurisdiction regardless of nationality.

This interpretation of the Treaty is corroborated by the Court's judgment in Spain $v$ UK. ${ }^{73}$ That case concerned the British legislation conferring the right to vote in elections to the EP on Commonwealth citizens resident in Gibraltar, that is TCNs. ${ }^{74}$ After review of the Treaty, the CJEU found that was possible, as the right to vote and stand for the EP was not necessarily limited to citizens of the Union. ${ }^{75}$ That rationale applies to Union action conferring the right to vote as well. Two conditions apply, however. UK v Spain demands there must be a sufficient link between the Union and the individual. This link will always be there in the case of those Union citizens who now

\footnotetext{
70 Decision by the EEA Joint Committee No 158/2007.

${ }^{71}$ EFTA Case E-4/11 Clauder (Liechtenstein), E-15/12 Wahl (Iceland), E-26/13 Gunnarsson (Iceland) and E-28/15 Jabbi (Norway).

${ }^{72}$ Case C-256/11, Murat Dereci and Others v Bundesministerium für Inneres, [2011] ECR I-11315.

${ }^{73}$ Case C-145/04, Spain v UK, [2006] ECR I-7961, para 70.

${ }^{74}$ Precedent for such extension of the franchise to non-nationals can be found in national constitutional law, for instance the Nordic countries.

${ }^{75}$ Spain v UK, para 74 reads as follows: "Moreover, while citizenship of the Union is destined to be the fundamental status of nationals of the Member States, enabling those who find themselves in the same situation to receive the same treatment in law irrespective of their nationality, ..., that statement does not necessarily mean that the rights recognised by the Treaty are limited to citizens of the Union".
} 
find themselves in the position of TCNs. There is possibly a second condition, although it was not articulated in that judgment as the case concerned a small group of people. For an extension of the franchise to a considerably larger group of TCNs, any distorting effects on the representative function will have to be taken into consideration. Again, that condition will be met by the number of British nationals residing in various other Member States relative to the number of Union citizens holding the nationality of a current Member State.

\section{The Treaty revision clause of Art. 25 TFEU}

Finally, Art. 25 TFEU does not stand in the way. It provides for a simplified revision procedure which relates to altering the content of the substantive rights already provided in primary law, by adding or strengthening. But continuing Union Citizenship and Associate Union Citizenship will stay within the perimeter of existing rights.

\section{PART TWO: FREEDOM OF MOVEMENT RIGHTS}

Part one elaborated that Brexit in accordance with the law includes a requirement that Union Citizenship and the associated rights are protected post-Brexit.

This part addresses the freedom of movement rights of economically active and economically inactive Union citizens and their family members, either from within the Union or from third countries. It explores the rights as enshrined in the Treaty law, the secondary legislation and the case law of the CJEU to give a clear picture of the system of existing rights. The law as it stands today marks the baseline for any future Withdrawal Agreement or Union legislation. Any departure from this baseline must comply with the law, in particular the principle of proportionality, the human rights standard, and the principle of non-discrimination.

\section{A. The legal possibility of securing freedom of movement rights post-Brexit}

The Treaty guarantees freedom of movement of Union citizens. The secondary law and the case law of the CJEU further shape the personal, material and temporal scope of application of these rights. Based on the conditions of an internationally lawful Brexit, the personal, material and temporal scope of application of freedom of movement rights remain unchanged post Brexit under the Continuity model. Union Citizenship is a fundamental status and protected as a legal situation created during the EU membership of the UK. This Continuity option, if fully implemented, does not entail any limitations on the material or personal scope of existing rights of those persons who have acquired Union Citizenship at the time the UK ceases to be a member of the EU. EU citizens who have exercised their freedom of movement rights enjoy the full and increased protection under existing EU law. Generally, the longer a person lives in another Member State, the better the legal status in accordance with the CRD and the more protection is provided by the existing law. ${ }^{76}$

\footnotetext{
${ }^{76}$ For a discussion of citizenship in Europe see N. N. Shuibhne, 'The Developing Legal Dimensions of Union Citizenship', in A. Arnull/D. Chalmers (eds), The Oxford Handbook of European Union Law, 477; D. Gosewinkel, Schutz und Freiheit? Staatsbürgerschaft in Europa im 20. und 21. Jahrhundert (2016), A. Lansbergen/J. Shaw, 'National membership models in a multilevel Europe', I.Con 8 (2010), 50, D. Kochenov, 'The Essence of EU citizenship emerging from the last ten years of academic debate: beyond the cherry blossoms and the moon?', ICLQ 62 (2013), 97, differentiating between
} 
Based on the arguments for a lawful Brexit, setting forth the existing bundle of rights is declaratory but necessary to guarantee legal certainty. This requires rule-making to extend these rights beyond the time when the UK ceases to be a member of the EU, either through legislation or through the Withdrawal Agreement. To achieve legal certainty, the personal, material and temporal scope of application of the freedom of movement rights must be clarified.

The law on freedom of movement rights does not exclude limitations. However, it requires limitations to be in accordance with the relevant legal standards. Any future limitation of the material, personal and temporal application of the freedom of movement rights must comply with the standard set out by the Treaty: the principle of proportionality, the fundamental human rights standard, and the principle of non-discrimination. This report does not argue in favour of any limitations. However, with regard to the system of freedom of movement rights, a limitation of the temporal scope of application of freedom of movement rights might safeguard the unity of the personal and material scope of rights. Differentiation in relation to the personal and material scope of application of these rights causes fractures to the consistency of the existing system of freedom of movement rights. By contrast, the law already applies a different standard of protection to Union citizens who have exercised their freedom of movement rights and those who have not. It is the exercise of the actual right that triggers increased protection of EU law. Those EU nationals who have not yet exercised their rights to freedom of movement have a legally protected expectation to enjoy freedom of movement rights at a later stage. A limitation of the period during which they can expect to enjoy freedom of movement rights in accordance with existing conditions may be a political compromise that could prevent changes regarding the personal and material scope of their application and also meet the criteria of the proportionality test. A detailed analysis of this would require a clear legal outline of the intended limitation. Returning to the starting point, even the introduction of a limit in relation to the temporal scope of application of freedom of movement rights is a derogation from the Continuity option and requires legislation to achieve a departure from the existing concretisation of the Treaty rights.

The introduction of a new concept of Associate Union Citizenship would permit further derogation from the existing rights of freedom of movement as set out in Union legislation and the case law. The existing law already uses categories to differentiate between economically active and inactive persons, mandatory and discretionary admissions of family members, and rights that can be enjoyed in relation to the accumulated periods of lawful residence. The introduction of Associate Union Citizenship would also require Union legislation. This legislation would need to meet the standard as set out by the Treaties. In the EU-27, any differentiation between UK associate Union citizens and all other Union citizens would be a differentiation based on nationality and thus especially concern the principle of non-discrimination.

The next section elaborates the standard for legislation on freedom of movement rights: first the Treaty (B), and second the fundamental human rights and general principles of law that govern the

three forms of acquisition of citizenship: ius sanguinis (acquisition of citizenship through birth from the parents), ius soli (acquisition of citizenship through birth in a certain country) and ius tractum (acquisition of citizenship through derivation), see also Opinion of AG P. Maduro, 30 September 2009, in Case C-135/08, Janko Rottmann v Freistaat Bayern, para 23. 
rule-making (C). The last section (D) focuses on the existing legislation on freedom of movement rights.

\section{B. Treaty law on freedom of movement rights}

This section provides an overview of the system of provision by the TFEU on freedom of movement rights. The starting point is the concept of Citizenship of the Union, Art. 20(1) TFEU. The treaty guarantees rights of EU citizens and especially workers' rights on a primary level. The rights that come with the status of Union Citizenship are not granted by any particular government, but through the existence of the European legal order.

In accordance with Art. 20(1) TFEU, every person holding the nationality of a Member State shall be a citizen of the Union. Union Citizenship is destined to be the fundamental status of the nationals of the Member States. ${ }^{77}$

All citizens of the Union have the right to enjoy the right to move and reside freely within the territory of the Member State, Art. 20(2) TFEU. These rights are to be exercised in accordance with the conditions and limits defined by the Treaties and by the measures adopted thereunder. In accordance with the case law of the CJEU, citizens of the Union 'enjoy the rights conferred by the Treaty and are subject to the duties imposed thereby. This cannot therefore be applied independently of the specific provisions of the Treaty which govern the rights and the duties of the citizens of the Union. ${ }^{178}$

Art. 21(2) TFEU provides that every citizen of the Union shall have the right to move and reside freely within the territory of the Member States, and reiterates that this right is subject to the limitations and conditions laid down in the Treaties and by the measures adopted to give them effect. The wording of Art. 21 TFEU lays down the primacy of law in the sense that the rights of freedom of movement can be limited and conditioned through treaty law and secondary legislation. Limitations placed on the primary rights through secondary legislation, must be subject to judicial review. $^{79}$

Art. 45 (1) TFEU guarantees a further right of Union citizens, the right to freedom of movement of workers. Such freedom shall entail the abolition of any discrimination based on nationality between workers of the Member States regarding employment, remuneration and other conditions of work and employment, Art. 45(2) TFEU. Moreover, in accordance with the case law of the CJEU, 'Art. 45 TFEU precludes any measure which, albeit applicable without discrimination on grounds of nationality, is liable to hinder or render less attractive the exercise by EU nationals of the fundamental freedoms guaranteed by the Treaty'. ${ }^{80}$ Limitations are possible on grounds of public policy, public security or public health, Art. 45(3). In addition, limitations can also be based on national legislation if the legislation pursues a legitimate aim compatible with the Treaty and if it is also justified by overriding reasons relating to the public interest. ${ }^{81}$

${ }^{77}$ Case C-184/99, Grzelczyk, 20 September 2001, para 31.

${ }^{78}$ Case C-420/15, U., 31 May 2017, para 17.

${ }^{79}$ Case C-413/99, Baumbast, 17 September 2002, para 86.

${ }^{80} U$., note 78 , para 20.

${ }^{81}$ U., note 78, para 29. 
Art. 45 TFEU provides for a primary right to freedom of movement and to reside freely for workers. Workers enjoy access to employment without discrimination and the right to equal treatment. ${ }^{82}$ Like Union citizens generally, workers can also convey a right to other persons. These are nonautonomous derived rights and can be enjoyed by Union citizens and third country nationals ${ }^{83}$, so called TCNs. Under certain conditions which are further detailed in the CRD, a Union citizen who does not qualify as a worker, can also convey a derived right to move and reside freely. By contrast, a TCN who obtains a derived right to move and reside freely and also works in the host Member State, does not acquire a primary right to move and reside freely. A TCN can acquire a derived right to move and reside freely, but cannot convey the right to other persons in accordance with EU law. Under further conditions, this derived right of a TCN may continue, on a strictly personal basis, for instance if the Union citizen who conveyed the right, dies or departs from the host Member State.

Art. 49 TFEU guarantees all Union citizens a primary right to be self-employed, subject to the same conditions as the nationals of the host Member State.

Three different categories of rights can be extrapolated from the existing law: The primary right (workers and Union citizens under certain conditions), the derived right (Union citizens and TCNs) and the right of residence exclusively on a personal basis (TCNs who for instance retain their derived right after the death of the Union citizen). Those rights have been further shaped in the citizenship directive 2004/38 (CRD) ${ }^{84}$ and, especially for workers, in Regulation 492/1185 and Directive $2014 / 54^{86}$. The case law of the CJEU further specifies the rights of workers and their family members, and those EU citizens who have exercised or wish to enjoy their mobility rights, on the basis of the CRD.

As will be discussed in detail in section $D$, the CRD covers all three categories of rights. It further differentiates between workers, self-employed persons, self-sufficient persons, students, and family members. The CRD fleshes out the rights of Arts. 20, 21, 45 and 49 TFEU, but the CJEU states that the CRD may not be interpreted as restricting the rights set out in the TFEU. Legislation on movement and residence cannot be interpreted restrictively in relation to the primary law. ${ }^{87}$ With regard to Art. 45 TFEU, for example, the CRD cannot limit the right of workers. The CRD facilitates the rights of Union citizens to move and reside freely within the territory of the Member States and cannot, by itself, limit the scope of the concept of worker as enshrined in the TFEU. ${ }^{88}$

\footnotetext{
${ }^{82}$ Regulation 492/11, chapter one: section one on eligibility for employment and section two on employment and equal treatment.

${ }^{83}$ Case C-202/13, McCarthy, 18 December 2014, para 34.

${ }^{84}$ Directive of $2004 / 38$ of 29 April 2004 on the right of citizens of the EU and their family members to move and reside freely within the territory of the Member States amending Regulation (EEC) No 1612/68 and repealing Directives 64/221/EEC, 68/360/EEC, 72/194/EEC, 73/148/EEC, 75/34/EEC, 75/35/EEC, 90/364/EEC, 90/365/EEC and 93/96/EEC, OJ L 158/78; OJ L 229/432004.

${ }^{85}$ Regulation (EU) No 492/2011 of 5 April 2011 on freedom of movement for workers within the Union, OJ L 141/1.

${ }^{86}$ Directive 2014/54/EU of 16 April 2014 on measures facilitating the exercise of rights conferred on workers in the context of freedom of movement for workers, OJ L 128/8.

${ }^{87}$ Case C-291/05, Eind, 11 December 2007, para 43, Case C-267/83, Diatta, 13 February 1985, paras 16 and 17; Case C-413/99, Baumbast, 17 September 2002, para 74.

${ }^{88}$ Case C-507/12, Jessy Saint Prix, 19 June 2014, para 32.
} 
This case law makes clear that future legislation would equally be set against the framework of the citizenship rights on a primary level. Whether this concerns limitations of rights or an entirely new concept of Associate Union Citizenship, the standard is set by the Treaty if the Treaty is to remain unchanged.

C. Fundamental rights and general principles of European Union law for rule-making for the time post-Brexit

Legislation in relation to freedom of movement rights needs to comply not only with the Treaty law on freedom of movement rights as discussed above, but also with the standards set by the principle of proportionality, fundamental human rights and equal treatment and non-discrimination.

\section{Proportionality}

The Treaty enshrines the principle of proportionality in Art. 5(4) TEU. Content and form of Union action must be proportional. The principle applies to all Union action. ${ }^{89}$ It safeguards the respect for the fundamental rights and freedoms of the EU Charter of Fundamental Rights, Art. 52(1) CFR and also of federal values..$^{90}$ Criteria that the proportionality principle comprises are set out in Protocol No 2. The underpinning rationale is that any restriction of a right strikes a fair balance between competing protected interests. ${ }^{91}$ The measure 'must be appropriate for securing the attainment of the objective which it pursues and must not go beyond what is necessary in order to attain it' ${ }^{92}$

Any limitation to the existing freedom of movement rights would also need to comply with this proportionality test. The measure would need to be suitable, necessary and proportional in the narrower sense. Suitability requires a reasonable connexion between the measure and the objective. The measure must be capable to attain the end.${ }^{93}$ Necessity means considering alternative options in order to rule out the possibility that the objective could be attained in some other way while at the same time providing better protection for other interests. The CJEU assesses whether there are less restrictive means that would serve the target but with a lesser impact on those other interests. Proportionality in the narrower sense entails the consideration of the measure in the light of all affected interests. A measure is only proportional in the narrower sense to the extent that the objective justifies a restriction of other interests.

\section{Fundamental human rights}

Any limitation of the right of freedom of movement must comply with the fundamental human rights standards. ${ }^{94}$ This concerns the EU internal human rights standards, as set out by the CFR, binding on the primary level in accordance with Art. 6(1) TEU. However, and most importantly in a situation of withdrawal of a Member State, it concerns the external, international standard of human rights protection. The CJEU ensures the observance of the rights as set out in the Convention

\footnotetext{
${ }^{89} \mathrm{R}$. Schütze, 'EU Competences, Existence and Exercise', in A. Arnull/D.Chalmers, The Oxford Handbook of European Union Law, 96.

${ }^{90}$ R. Schütze, note $89,97$.

${ }^{91}$ Case C-60/00, Carpenter, 11 July 2002, para 43.

${ }^{92}$ Case C-100/01, Olazabal, 26 November 2002, para 43.

${ }^{93} \mathrm{C}$. Barnard, The substantive law of the EU, 178.

${ }^{94}$ Carpenter, note 91 , paras 40 and 41.
} 
for the Protection of Human Rights and Fundamental Freedoms (ECHR). Especially, the protection of family life under Art. 8 ECHR for Union nationals may make the removal of a person from the territory of a Member State unlawful, in particular where close members of the family are living in the Member State concerned. The CJEU in its case law confirms that the respect for family life as guaranteed by Art. 8 ECHR belongs to the fundamental rights which are protected by Union law. ${ }^{95}$

Limitations placed on the right of freedom of movement would have to comply with the standard of the ECHR.

\section{Equal treatment and non-discrimination}

Art. 18(1) TFEU states that within the scope of application of the Treaties, any discrimination on grounds of nationality shall be prohibited. The case law of the CJEU makes clear that every citizen of the Union may rely on Art. 18 TFEU in all situations within the material scope of application of EU law, including the exercise of the freedom conferred by Art. 21 TFEU to move and reside within the territory of the Member States. ${ }^{96}$ Treaty law may specify non-discrimination in relation to certain areas. For instance, Art. 45 TFEU is lex specialis to Art. 18 TFEU. The CJEU has confirmed that Art 18 TFEU, 'applies independently only to situations governed by EU law for which the Treaty lays down no specific rules of non-discrimination. In relation to the freedom of movement for workers, the principle of non-discrimination was implemented by Art. 45 TFEU'. ${ }^{97}$

Associate Union Citizenship would have to compatible with the principle of non-discrimination, creating a new status with a new bundle of rights. The Commission requests in its Working paper 'Essential Principles on Citizens' Rights' of 31 May 2017, equal treatment in the UK of EU 27 citizens as compared to UK nationals. A note of caution might be necessary to limit this to social advantages. For the position of third country nationals, who obtain a derived right of residence from their Union citizen spouse, equal treatment of EU citizens and UK nationals in general might not always be beneficial. At the moment for instance, third country nationals who live with their British spouse or partner in the UK, do not benefit from EU citizenship rights at all. In those situations, stricter UK immigration rules are applicable, which establish conditions that need to be satisfied for third country nationals to live in the UK. Only in cases where the UK citizen returns to the UK after having exercised the right to freedom of movement, does the CJEU apply the freedom of movement rights as set out in the CRD by analogy (return situation). It is not yet clear whether the CJEU will expand this analogy in cases where the EU citizen acquires citizenship of the UK through naturalisation and thereby diminishes the protection of the third country national under EU law. ${ }^{98}$ If, in future, Union citizens of EU 27 are to be treated equally with UK nationals in the UK, then this might result in a wider application of UK immigration rules. Such a change would be a derogation of the protection of Union citizen as guaranteed in the existing law.

\footnotetext{
${ }^{95}$ Case C-441/02, Commission v Germany, 27 April 2006, para 109.

${ }^{96}$ Case C-73/08, Nicolas Bressol and Others, 13 April 2010, para 31, Case C-209/03, Bidar, 15 March 2005, paras 32 and 33; and Case C-158/07, Förster, 18 November 2008, paras 36 and 37.

${ }^{97}$ Case C-420/15, U., 31 May 2017, para 16.

${ }^{98}$ Advocate General Y. Bot, Toufik Lounes v Secretary of State for the Home Department, Court of Justice of the European Union, Press Release No 56/17, 30 May 2017.
} 


\section{Citizens' free movement rights in existing legislation and case law}

The citizenship rights to move, reside and to equal treatment are consolidated in the Citizenship Directive. The Directive sets out the personal and material scope of freedom of movement rights. Two main factors drive the protection of freedom of movement rights. First of all, it is the actual exercise of the right to freedom of movement that triggers the protection under EU law, in accordance with the CRD, applied in the light of the Treaties. ${ }^{99}$ Secondly, the longer the duration of stay of a person in a host Member State, the more rights they enjoy. ${ }^{100}$ Both of these aspects will be relevant to the consideration of any limitations of the scope of application, if such limitations are politically demanded.

\section{Personal scope of application}

The Directive applies to Union citizens and their family members, Art. 3(1) CRD.

As mentioned above, three main categories of rights exist, the primary rights, the derived rights and the rights exclusively on a personal basis.

Primary rights are conferred, in accordance with the CRD, on EU citizens who are engaged in an economic activity, or are job-seekers, or students, or are self-sufficient.

Derived rights are those that family members irrespective of their nationality may obtain from the Union citizen, provided they are descendants or dependants, were members of the household of the Union citizen in their home state, or where the Union citizen delivers the personal care of the family member as strictly required by serious health grounds or are the spouse or registered partner or a partner with whom the Union citizen has a durable relationship, duly attested.

The rights on an exclusively personal basis are those derived rights that a TCN can retain under certain circumstances, in cases where the person with the primary right discontinues to convey the right to the TCN.

For the primary and derived rights, the content of the right of freedom of movement is further differentiated in line with the movement of the Union citizen, which includes the right to leave the home member State and to return to it, the right of entry into another Member State and the right of residence. The following section examines the different rights of Union citizens and their family members from the perspective of the movement options of exit and return, entry and residence in the host member. After an initial period of three month, the Union citizen's primary right depends on further conditions and varies accordingly. At this point of time, it is crucial to determine whether the Union citizen is economically active or not. ${ }^{101}$ This status then also influences the status of those whose rights are derived from the respective Union citizen. Again, the aim is to illustrate where the existing body of law already conditions the different freedom of movement rights and how categories are installed.

\footnotetext{
${ }^{99}$ Case C-133/15, Chavez-Vilchez and Others, 10 of May 2017, para 52.

${ }^{100}$ C. Barnard, note 93, p. 205.

${ }^{101}$ C. Barnard, note 93, p. 332.
} 


\section{Union citizens}

A Union citizen is defined as any person having the nationality of a Member State, Art. 2(1) CRD. Post Brexit, the crucial question will be to establish that those UK nationals who have acquired Union Citizenship retain Union Citizenship, even though they do not possess the nationality of a Member State. This report argues that the membership of the UK of the EU has created a legal situation that is protected under international law post-Brexit. The Union Citizenship that was acquired during the time the UK was a member of the EU, is part of that legal situation and continues.

\section{This has the following consequences for Union citizens:}

- Those persons who have exercised their free movement rights and live in another Member State, and this concerns UK nationals living in EU-27 and EU-27 nationals living in the UK, retain their entire status and all associated rights that come with that status. They can also accumulate periods leading to the right of permanent residence.

- For those EU-nationals and UK nationals who have not exercised their citizenship rights of freedom of movement, a dormant right continues to exist. This includes their right to exercise freedom of movement rights at a later stage and to accumulate relevant periods for the right of permanent residence.

- This interpretation does not include Union Citizenship rights for unborn UK nationals. Likewise, unborn children of EU-27 nationals have not gained their Union Citizenship as part of a legal situation of UK membership of the EU and thus, would not be entitled to any rights of freedom of movement in relation to a the UK as former EU Member State on the basis of their (own) Union Citizenship rights, although they may hold derived rights.

Depending on the political circumstances, the legally sound Continuity option might be rather difficult to sustain and can be combined with time limits under the Withdrawal Agreement for those who have not exercised their freedom of movement rights (dormant rights). Any such limitation would be constitutive in the sense that is would change the law. Likewise, the creation of new Associate Union Citizenship rights in a Withdrawal Agreement, would be constitutive and a derogation of existing law.

\section{Mandatory admissions of family members}

The CRD distinguishes between those family members who enjoy a mandatory right of entry and residence if further conditions are fulfilled, Art. 2(2), Art. 3(1)1 CRD, and those family members, whose entry and residence the host State must merely facilitate, Art. 3(2) CRD.

Family members whose admission is mandatory include the spouse, the partner with whom the citizen maintains a registered partnership, provided that the home Member State and the host Member State both recognize the form of partnership, the direct descendants who are under the age of 21 or are dependants and those of the spouse or partner, and the dependent direct relatives in the ascending line and those of the spouse or partner, Art. 2(2) CRD.

The protection of family life of Union citizens is an important factor that drives family re-unification and family formation. In contrast to an earlier judgment of the CJEU in Akrich, the CJEU now 
considers since Metock that based on the fact that the CRD does not distinguish between family members who have already resided lawfully in a member state and those who have not, the admission of family members cannot be made dependent on a rule of prior lawful residence either. ${ }^{102}$ In overturning an earlier ruling that only those TCN spouses that already resided lawfully were allowed to accompany or follow the Union citizen into another member state, ${ }^{103}$ the CJEU held that national legislation requiring the lawful residence of a TCN family member for entry and admission to a member state in order to join or accompany a Union citizen as not compatible with the objective of an internal market and the securing of its fundamental freedoms. ${ }^{104}$

\section{Discretionary admissions of family members}

There are two groups of family members whose admission the host Member State must facilitate, Art. 3(2) CRD.

The first group concerns all other family members not covered by Art. 2(2) CRD, who 'in the country from which they have come, are dependants or members of the household of the Union citizen having the primary right of residence, or where serious health grounds strictly required the personal care of the family member by the Union citizen' (a).

The second group includes the partner of the Union citizen, who has contracted a durable relationship with the Union citizen which can be duly attested (b).

In accordance with the term 'must facilitate' in the second paragraph, the provision continues by setting out a strong legal presumption in favour of admission of those family members. It states that the host Member State shall examine the personal circumstances and that is shall justify any denial of entry of residence. This interpretation can be further substantiated in the light of the preamble of the directive, which states in recital 6:

'In order to maintain the unity of the family in a broader sense and without prejudice to the prohibition of discrimination on grounds of nationality, the situation of those persons who are not included in the definition of family members under this Directive, and who therefore do not enjoy an automatic right of entry and residence in the host Member State, should be examined by the host Member State on the basis of its own national legislation, in order to decide whether entry and residence could be granted to such persons, taking into consideration their relationship with the Union citizen or any other circumstances, such as their financial or physical dependence on the Union citizen.'

The CJEU held in Rahman that Art. 3(2) CRD is not directly applicable, and that Member States are required to adopt national legislation that incorporates criteria that correspond to the meaning of the term 'facilitate' and do not deprive Art. 3(2) CRD of its effectiveness. ${ }^{105}$ However, the CJEU also acknowledges that Member States have discretion in the selection of those criteria and that the CRD

\footnotetext{
${ }^{102}$ C-127/08, Metock, 25 July 2008, 67, 80.

${ }^{103}$ Case C-109/01, Akrich, 23 September 2003, para 50 and 51.

${ }^{104}$ Metock, note 102, para 68.

${ }^{105}$ Case C-83/11, Rahman 5 September 2012, para 24.
} 
does not stipulate that Member States must grant a right to reside in all cases. Each Member State must however provide for judicial review of the national legislation and its application. ${ }^{106}$

If the right to join the Union citizen is based on the element of dependency, the applicant must prove that dependency existed in the country from which the family member concerned comes, at the very least at the time when the application to join the Union citizen on whom he/she is dependent is submitted. ${ }^{107}$

\section{Substantive scope of application}

The Citizenship Directive sets out different rights in relation to the relevant movement options.

\section{The right to leave the home member State and to return to the home member State}

Art. 4 CRD provides the right to exit any member State, including the home member State, for all Union citizens with a valid identity card or passport. The provision requires family members who are not nationals of a Member State to hold a valid passport. Art. 4(2) stipulates that no exit visa or equivalent formality may be imposed on the persons who are either Union citizens and hold an identity car or passport or are TCN family members and provide a valid passport.

The right to return to the home Member State is not covered by the Directive but by the Treaty. ${ }^{108}$ Strictly speaking, the situation is from the moment the Union citizen enters the home country, wholly internal. However, if the Union citizen is hindered in returning to his/her home country, the CJEU considers that this has a deterrent effect for those who seek employment in other Member States and who are confronted with the uncertainty that they firstly, might not be able to return to their home country and secondly, might not be able to be accompanied by their family members. The CJEU in those situations applies the Directive by analogy to give effect to the Treaty rights.

In a series of judgments concerning these return situations, the CJEU cautiously started by stating that the right of a worker to leave the home country to take up work in another Member State would be restricted if the citizen could not return to the home country, even if the citizen ceased to be a worker. The CJEU considered this as being necessary for the enjoyment of the right of freedom of workers under the conditions set out in the secondary legislation. Furthermore, the CJEU held that this interpretation was further substantiated by the introduction of the status of citizen of the union. ${ }^{109}$

This jurisdiction was elaborated and clarified when the CJEU concluded that, when a Union citizen returns to the Member State of which he/she is a national, the conditions for granting a derived right of residence to a TCN family member should not be stricter than those provided for by the CRD in situations where the Union citizens becomes established in a Member State of which he/she is not a national. ${ }^{110}$

\footnotetext{
${ }^{106}$ Rahman, note 105, para 25.

${ }^{107}$ Rahman, note 105 , para 35.

${ }^{108}$ C. Barnard, note 93, p. 340.

${ }^{109}$ Case C-291/05, Eind, 11 December 2007, para 32.

${ }^{110}$ Case C-456/12, O. and B., 12 March 2014, para 50.
} 
From there, it was only a small step for the CJEU to take this case law further. In a recent judgment, the CJEU also applied the CRD by analogy to a situation where a child returned to its EU home country, with its TCN mother. The CJEU came to the conclusion that while the CRD does not cover such a return, it should be applied, by analogy, in respect of the conditions that it lays down for the residence of a Union citizen and the derived right of the TCN in a Member State other than that of which he/she is a national. ${ }^{111}$ It might be useful to bear in mind that the free movement rights will necessarily prove to be most controversial in those instances where EU law is applied in the case law to wholly internal situations.

\section{The right of entry into the host Member State}

\section{a) Union citizens}

All Union citizens shall have the right to enter the territory of another Member State, Art. 5(1) CRD. The CRD uses mandatory language when requiring Member States to grant Union citizens leave to enter their territory with a valid identity card of passport. No entry visa or other formality can be imposed to restrict their right to entry. If the Union citizen is unable to present a valid identity card or passport, the Member State is obliged to give them every reasonable opportunity to obtain the necessary documents, Art. 5(4) CRD. The person concerned can be required to inform the Member State of his/her presence, Art. 5(5) CRD.

b) Third country family members

Member states shall also grant leave to family members who are not nationals of a Member State to enter their territory, Art. 5(1) CRD. TCNs are required to provide a valid passport, unless they are in possession of a valid residence card, Art. 5(2), Art. 10 CRD. The host Member State is not entitled to place an entry or exit stamp in the passport of a TCN family member, provided that the residence card is presented. Art. 5(3) CRD. TCNs can be required to obtain an entry visa in accordance with Regulation (EC) No 539/2001, or with national law, Art. 5(2) CRD. These visas shall be issued free of charge as soon as possible in an accelerated procedure. If TCN family members are unable to submit the correct documentation at the point of entry into a Member State, the Member State shall give such persons every reasonable opportunity to obtain the necessary documents, Art. 5(4) CRD. Member States can require those persons to report their presence within their territory within a reasonable and non-discriminatory period of time.

However, the possession of the relevant certificates is not a condition required for the Union citizen to exercise the right to residence and to start work, Art. 25(1) CRD. ${ }^{112}$ Moreover, detention and deportation based solely on the failure to comply with legal formalities concerning the monitoring of aliens are a serious violation of the right to residence. ${ }^{113}$

The CRD covers situations of family members accompanying or joining the Union citizen. It thus provides for re-unification and for family formation likewise. The UK is not bound by the Family reunification Directive 2003/86. ${ }^{114}$

${ }^{111}$ Chavez-Vilchez, Case C-133/15, 10 of May 2017, para 55.

${ }^{112}$ C. Barnard, note 93, p. 343.

${ }^{113}$ Case C-215/03, Oulane, 17 February 2005, para 40.

${ }^{114}$ Council Directive on the right to family reunification, 22 September 2003, OJ L 251/12. 


\section{The right of residence for the first three months}

As long as the Union citizens holds a valid identity car or passport, no further conditions apply to the right to reside for the first three month after entry into the host State, Art. 6(1) CRD. Likewise, the TCN family members are free to accompany or join the Union citizens during this timeframe without any further constraints, subject to the validity of their passports, Art. 6(2) CRD. During these first three months, no right to social assistance exists for Union citizens.

\section{The right of residence between three months and five years}

The most differentiated period in relation to the right to reside is the period after three months up until 5 years, as provided for in Art. 7 CRD.

It is the three months threshold that sets the line of departure for the differentiation between those Union citizens who are economically active and those who are not. After three months, the right to reside is limited to those Union citizens who have sufficient resources, through economic activity or other means, and who consequently are very unlikely to become an unreasonable burden to the social assistance system of the respective Member State. ${ }^{115}$

a) The worker, self-employed and the jobseeker

The CJEU defined a "worker" as a person who is employed for a period of time in the provision of services for and under the direction of another in return for remuneration. The definition of worker is based on a broad understanding of the term and includes part-time work and work that is not sufficient to safeguard subsistence of the worker and his/her family. One relevant consideration when excluding marginal work from genuine employment might be whether another employee would need to be found to do the work instead. ${ }^{116}$

Art. 7(1) (a) CRD puts the worker on a par with the self-employed Union citizen after the three months threshold.

Primary law and the CRD provide no definition for the term self-employment. The CJEU interprets Art. 49 TFEU broadly and recognises that self-employment includes any 'economic activities carried out by a person outside any relationship of subordination with regard to the conditions of work or remuneration and under his own personal responsibility'. ${ }^{117}$ The possible activities that can qualify as self-employment are understood broadly ${ }^{118}$, and the CJEU emphasises the right of the self-employed person to participate economically in a Member State other than his/her State of origin on a stable and continuous basis. ${ }^{119}$

Art. 45(3) TFEU protects the right for those actions of the individual surrounding the right of actually staying in a Member State for the purpose of employment (c). This includes the acceptance of offers of employment that have been made (a), to move freely with the territory of the members states for this purpose (b), and to remain in the territory of a Member State after the employment ends, subject to further secondary legislation (d). Read on its face, it is not clear whether (b) only refers to

\footnotetext{
${ }^{115}$ C. Barnard, note 93, p. 332.

${ }^{116}$ Question posed by the Court of Justice of the European Union in Genc and by the Court of Appeal of England and Wales in the case of Barry v London Borough of Southwark [2008] EWCA Civ 1440.

${ }^{117}$ Case C-268/99, Jany, 20 November 2001, para 37.

${ }^{118}$ C. Barnard, note 93, p. 242.

${ }^{119}$ Case C-55/94, Gebhard, 30 November 1995, para 25.
} 
moving freely in the territory for the purpose of accepting the already made offer of employment, or whether it more broadly refers to the purpose of seeking such offers. In Antonissen, the CJEU assumed the protection of the job-seeker under Art. 45(3) TFEU, in stating that without a clear time frame given in EU law, a period of six month as provided in national legislation may be sufficient for the job-seeker to be able to take up work. However, if after that period of time the job-seeker can evidence that the work search continues and that there are genuine chances of being employed, the person cannot be required to leave the territory of the respective Member State. ${ }^{120}$

\section{b) The non-economically active citizen}

This right to reside after three months is extended to those who are not economically active, but have sufficient resources for themselves and their family members, Art. 7(1)(b). The CRD defines as sufficient resources those that prevent not only the Union citizen but also his/her family members from becoming a burden on the social assistance system of the host Member State during their period of residence and include comprehensive sickness insurance cover in the host member State.

The Member State is entitled to undertake all checks as necessary to establish that the resources are existent, and available. ${ }^{121}$

\section{c) Students}

The student who is enrolled at a private or public establishment that is accredited or financed by the host Member State, and who does actually follow a course of study including vocational training, also obtains a primary right to reside, Art. 7(1)(c) CRD. The student also has to have comprehensive sickness cover and sufficient means for his/her subsistence and for the reduced group of family members who obtain their derived right from the student. These include only the spouse or registered partner and dependent children. They acquire a mandatory right of admission. The host State has discretion with regard to the admission of the dependent direct relatives in the ascending lines and those of the spouse or partner, Art. 7(4) CRD.

Whether or not the student has sufficient resources, must be assessed at the time when the declaration was made, as it might change during the course of study. ${ }^{122}$

Member States are not obliged to grant maintenance aid for studies, including vocational training, prior to the acquisition of the right of permanent residence, Art. 24(2) CRD. Maintenance aid includes student grants or student loans. This exemption is not applicable if the person is a worker, self-employed person, or a person who retains such status or a family member of such a person.

\section{The right of permanent residence, duration of residence, continuity and exceptions} Union citizens obtain the right of permanent residence after residing legally in the host Member State for a continuous period of five years, Art. 16(1) CRD. The limitations as set out in the CRD for the period for up to five years do not apply after the right of permanent residence is acquired. TCN family members who have legally resided with the Union citizen for the period of five years also acquire the right of permanent residence, Art. 16(2) CRD.

\footnotetext{
${ }^{120}$ Case C-292/89, Antonissen, 26 February 1991, para 21.

${ }^{121}$ Case C-408/03, Commission v. Belgium, 24 May 2011, para 44.

${ }^{122}$ Case C-184/99, Grzelczyk, 20 September 2001, para 45.
} 
The CRD also clarifies the term continuity. During each year of legal residence counting towards the five years, a period of up to six months of absence from the host Member State does not affect the continuity of residence. Absences for a not further specified duration for compulsory military service similarly leave the continuity of residence unaffected. One absence of a maximum of 12 months during the five years period for important reasons such as pregnancy and childbirth, serious illness, study or vocational training, or a posting in any other state, is also possible, Art. 16(3) CRD.

After acquiring the right of permanent residence, this can only be lost through absence from the host Member State for a period of more than two consecutive years, Art. 16(4) CRD.

There are certain exemptions o the general five year rule on acquisition of permanent residence.

Before the completion of the five years period, workers or self-employed persons who have reached the retirement age of the host Member State, have worked in that Member State for a least the preceding 12 months and have resided there continuously for more than three years, have the right of permanent residence. This exemption also applies to workers who take early retirement. If the host Member State does not provide for the right for self-employed persons to an old age pension, the CRD lays down that the age condition shall be satisfied once the persons reaches an age of 60 , Art. 17(1)(a).

If a worker becomes permanently incapable to work and stops working for that reason, after a period of two years of residence, the person also acquires the right of permanent residence before exceeding the five years period, Art. 17(1)(b) CRD. Furthermore, if the incapacity to work results from a work-related accident or an occupational disease and the worker is entitled to a benefit by an institution in the host Member State the duration of residence is no longer a factor for the right of permanent residence.

In cases where the worker or self-employed person is married to or a partner of a Union citizen who is a citizen of the host Member State, or has lost that citizenship through marriage to the worker or self-employed person, no conditions regarding the duration of residence and employment are applicable, Art. 17(2) CRD.

If, after three years of continuous employment and residence in the host Member State, the worker or self-employed person becomes a worker or self-employed person in another Member State, but retains residence in the host Member State and as a rule, returns each day or at least once a week, the right of permanent residence is also acquired before the five years are completed, Art. 17(1)(c).

Union citizen family members and TCN family members who are residing with the primary Union citizen also acquire the right of permanent residence in the situation of retirement and incapacity to work, or if the Union citizens starts working in another Member State while still residing in the host Member State after working there for three continuous years, Art. 17(3) CRD.

However, the CRD lays down that in the case of the death of the Union citizen, the right of permanent residence becomes detached from the primary right and is extended in favour of the derived right of the family members who are residing with him/her, Art. 17(4) CRD.

If the worker dies while still working and before acquiring the right of permanent residence, the family members can obtain the right of permanent residence if the worker or self-employed person 
had already resided continuously on the territory of the host Member State for two years, or the death resulted from an accident at work or an occupational disease, or the surviving spouse lost the nationality of the host Member State following marriage to the worker or self-employed person, Art. 17(4) CRD. It is worth mentioning that this provision excludes the right of family members who joined the Union citizen too late to fulfil any relevant periods of parallel residence, if applicable.

\section{The equal treatment rights in relation to the welfare state}

The CRD sets out in Art. 24(1), that all union citizens residing in the host Member State have the right to be treated equally with nationals of that Member State. This right is extended to TCN family members under the condition that they have the right to reside or the permanent right of residence, Art. 24(1) CRD. Exceptions are however possible, especially prior to the acquisition of the right of permanent residence, Art. 24(2) CRD. As detailed below, Member States are not obliged to grant social assistance for the first three month or to jobseekers more generally. Furthermore, maintenance aid for studies and vocational training does not have to be granted, unless the applicant is also a worker, a self-employed person or a person who retains such status or a family member of such a person.

\section{a) Social Assistance}

One major concern of host Member States is abusive recourse to their social assistance system.

The CJEU has defined the term 'social assistance' as covering

'all assistance introduced by the public authorities, whether at national, regional or local level, that can be claimed by an individual who does not have resources sufficient to meet his own basic needs and the needs of his family and who, by reason of that fact, may become a burden on the public finances of the host Member State during his period of residence which could have consequences for the overall level of assistance which may be granted by that State'. ${ }^{123}$

Economically non-active persons, such as students, job-seekers, unemployed and the retired must as a general rule have for themselves and their family sufficient financial means so as not to become a burden on the host EU country's social assistance system as well as health insurance.

Each Member State has its own welfare system, which also is a devolved competence in some Member States. The EU only has the competence to coordinate, but not to harmonize national legislation. ${ }^{124}$ Welfare rights normally provided by states can be classified into two different groups. The first group concerns social assistance benefits.

The Commission defined social assistance as 'subsistence benefits' that 'typically consists of benefits paid to cover minimum living expenses or assistance paid for special circumstances in life.'

By contrast, social security benefits cover old age pension, survivor's pension, disability benefits, sickness benefits, birth grant, unemployment benefits, family benefits or health care. ${ }^{125}$

${ }^{123}$ Case C-140/12, Peter Brey, 19 September 2013, para 61.

${ }^{124}$ Regulation No 883/2004 on the coordination of social security systems, 29 April 2004, OJ L 166/1.

125 http://europa.eu/rapid/press-release_MEMO-14-9_en.htm. 
For the first three months, the host EU Member State is not obliged by EU law to grant social assistance to economically non-active EU citizens, Art. 24(2) CRD. This period can be extended, if the search for work continues, Art. 24(2) CRD in conjunction with Art. 14(4)(b) CRD.

Between three months and five years, the worker and the self-employed person enjoy the same right to social assistance as the nationals of the host state. Economically non-active EU citizens would by the application for any form of social assistance contradict the grounds on which their right to reside was established. They had to demonstrate that they had sufficient resources. At the same time, however, Art. 14(3) CRD sets out the limits of the measure that the host State may decide to adopt. In assessing whether an individual whose resources can no longer be regarded as sufficient has become an unreasonable burden, the authorities of the Member States must carry out a proportionality test. ${ }^{126}$ In those cases the host State may not automatically take any expulsion measure against the Union citizen who makes recourse to the social assistance system of the host Member State. If such recourse is however made then this might give rise to reasonable doubt as to whether the Union citizen or his/her family members meet the requirements of self-sufficiency, Art. 14(3) CRD.

If, however, the worker or the job seeker becomes a burden on the social assistance system, an expulsion measure cannot be justified on that ground, Art. 14(4) CRD. For the jobseeker, this guarantee however depends on the job-seeker's continuous search for work and the evidence of a genuine chance of employment, (b).

Job-seekers can export unemployment benefits received from their home Member State for a minimum of three months while seeking work in another Member State, provided they have first been registered as unemployed in their home Member State. ${ }^{127}$ In the UK, job-seekers are entitled to job-seeker's allowance after the first three month, provided they pass the habitual residence test, i. e. the person resides legally and intends to settle in the UK. This legislation was introduced in April 2014. ${ }^{128}$

\section{b) Comprehensive sickness cover}

All Union citizens and their family members, irrespective of their nationality, must have comprehensive sickness cover in the host Member State, if they are not economically active, Art. $7(1)(b),(c),(d)$ CRD.

The Commission guidance on comprehensive sickness cover provides that 'any insurance cover, private or public, contracted in the host Member State or elsewhere, is acceptable in principle, as long as it provides comprehensive coverage and does not create a burden on the public finances of the host Member State.' For pensioners, it is deemed to be sufficient to be entitled to health care on behalf of the Member State which pays their pension. ${ }^{129}$

UK Home Office guidelines assert that possession of a European Health Insurance Card (EHIC) is sufficient to establish comprehensive sickness cover. Furthermore, it states that 'After five years of continued UK residence a citizen would not be eligible for this document from their Member State of

${ }^{126} \operatorname{COM}(2009) 313$ final, p. 8.

127 http://europa.eu/rapid/press-release_MEMO-14-9_en.htm.

${ }^{128} \mathrm{https}$ ://www.gov.uk/government/news/new-rules-to-stop-migrants-claiming-housing-benefit.

${ }^{129} \mathrm{COM}(2009) 313$ final, p. 9, see also Regulation (EC) No 883/04. 
origin. The guidelines also make it clear that access to the NHS alone is not sufficient proof, though it is believed that the Commission had presumed this would satisfy the requirement when drafting the original legislation. The same guidelines make clear that an S1 form would also fulfil the CSI requirement. ${ }^{130}$

\section{Administrative formalities for the right of residence of Union citizens}

The CRD differentiates between three different formalities in relation to the duration of the stay of the person concerned, and in relation to whether the person is a Union citizen or a TCN family member.

\section{a) Registration certificate}

The host Member State has the right to require all Union citizens to register with the relevant authorities after a period of three month, Art. 8(1) CRD. A registration certificate must then be issued by the host Member State. Non-compliance with this requirement may be sanctioned in a proportionate and non-discriminatory way, Art. 8(2) CRD.

To issue such a registration certificate, Member States may only require that the Union citizen presents a valid identity card or passport. In addition to that and depending on the criteria the Union citizens claims with regard to Art. 7(1) CRD, the host Member State may require proof of the economic activity, proof of the resource for those claiming to be self-sufficient, or proof of enrolment at an accredited establishment as well as proof of comprehensive sickness insurance cover, Art. 8(3) CRD.

With regard to the qualification of resources as being sufficient, the CRD prevents Member States from adopting a fixed amount for what they regard as satisfying the criteria of sufficiency. Art. 8(4). They must take consider the personal situation based on case by case consideration. Furthermore, the amount shall not be higher than 'the threshold below which nationals of the host Member State become eligible for social assistance' or if that is not applicable 'higher than the minimum social security pension paid by the Member State.

The CRD differentiates between the administrative requirements which the family members must satisfy, Art. 8(5) CRD. Family members who are Union citizens are eligible for a registration certificate if they present a valid identity card or passport and proof that they satisfy any further conditions of their derived right, i.e. the family relationship or partnership status (a), the registration certificate of the Union citizen whom they are accompanying or joining, the fact that they are dependants under the age of 21 of the Union citizen or the spouse or partner, or that they are dependent direct relatives in the ascending line of the Union citizen or the spouse or partner, Art. $8(5)(d)$.

In cases where the host State must merely facilitate the admission of the Union citizen's family members, who are Union citizens, the authorities may require a document issued by the relevant authority of the country of origin or the country from which the person is arriving which certifies that the family member is a dependant or member of the household of the Union citizen, or proof of

${ }^{130} \mathrm{http}: / /$ www.europarl.europa.eu/sides/getDoc.do?type=WQ\&reference=P-2017001467\&format $=X M L \&$ language $=E N$. 
serious health grounds which require the personal care of the family member by the Union citizen, Art. 8(5)(e).

If the Union citizen family member wants to accompany or join the Union citizen and claims the existence of a durable relationship, the host Member State may require proof of that, Art. 8(5)(f).

b) Residence card

A TCN family member must apply for residence card, however the deadline for the application may not be less than three months from the date of arrival, Art. 9(1) and (2) CRD.

Failure to comply may trigger proportionate and non-discriminatory sanctions, Art. 9(3) CRD.

The right of residence of the TCN family member must be evidenced through the residence card which must be issued no later than six months from the date of the application, Art. 10(1) CRD.

The CRD uses mandatory language when referring to the documents that TCN family members must submit with their application for a residence card. By contrast, the CRD leaves the presentation of documents for the registration of Union citizens to the discretion of the Member States.

For TCN family members, the host State shall require a valid passport (a), a document attesting the existence of the claimed family relationship or partnership (b), either the registration certificate of the Union citizen or other proof of residence of the Union citizen in the host Member State (c), proof of the fact that they are dependants under the age of 21 of the Union citizen or the spouse or partner, or that they are dependent direct relatives in the ascending line of the Union citizen or the spouse (d). In cases where the host Member State has discretion regarding the admission of the family member, the host Member State shall require a document issued by the relevant authority of the country of origin or the country from which the person is arriving which certifies that the family member is a dependant or member of the household of the Union citizen, or proof of serious health grounds which require the personal care of the family member by the Union citizen (e). If a right is claimed based on the fact of a durable relationship, the host Member State is obliged to require proof that the durable relationship exists.

The residence card for TCN family members is valid for five years or for a shorter period, if the Union citizen's duration of stay is less than five years, Art. 11(1) CRD.

The validity of the residence card is not affected, if the TCN family members does not exceed temporary absences of six months per year. Likewise, one absence of 12 consecutive months for important reasons such as pregnancy or childbirth, serious illness, study or vocational training, or a posting in another Member State, leave the validity unaffected. The absence can be even longer in cases of compulsory military services, Art. 11(2) CRD.

\section{c) Permanent Residence Card}

Member states are under the obligation to issue a document certifying permanent residence as soon as possible to those Union citizens who have acquired the right and applied for the document, Art. 19 CRD.

TCN family members who are entitled to permanent residence and apply for residence cards shall receive the card within six months of application, renewable automatically every 10 years, Art. 20(1). 
A TCN family member who applies for a permanent residence card must submit the application during the period where the residence card is still valid. Otherwise, proportionate and nondiscriminatory sanction might apply, Art. 20(2) CRD. An interruption of residence of less than two consecutive years does affect the validity of the permanent residence card, Art. 20(3) CRD.

\section{d) Continuity}

The CRD provides that the respective continuity of residence may be attested by any means of proof that the host Member States uses and acknowledges, Art. 21 CRD.

\section{Territorial and temporal scope of application}

The right of residence and the permanent right of residence apply within the entire territory of a Member State, Art. 22 CRD. Any territorial restriction of these rights must equally apply to the Member State's own nationals. ${ }^{131}$ No restriction applies in relation to the temporal scope of freedom of movement rights so far. Union Citizenship entails the right to exercise the right to move and reside freely, including the choice of time to move to another Member State. It covers the legal expectation of enjoying the right at any stage during the lifetime of a Union citizen, without the prospect of losing the entitlement to exercise the right if it is not exercised (dormant right). If the Withdrawal Agreement, for instance, were to introduce a time limit for the application of the existing law, then this would be a restriction that would need to comply with the rights and principles guiding new legislation regarding freedom of movement rights.

\section{Retention of status, change of status and restrictions}

\section{Retention of the right of residence for the Union citizen}

The right to reside shall be retained for the Union citizen and their family members, as long as they fulfil the criteria of Art. 7, 12, 13 and provided they do not become an unreasonable burden on the social assistance system of the host Member State, Art. 14(1) and (2) CRD.

If the Member State has reasons to doubt that the conditions are met, it may undertake their verification. However, a systematic verification without initial doubt shall not be entailed, Art. 14(2) CRD. An expulsion measure is not excluded by Art. 14(3) CRD, however, it shall not be the automatic response of a Unions citizen's or his/her family members' recourse to the social assistance system. An expulsion measure is not excluded on the ground of the Union citizen or his/her family members turning to the social assistance system, but firstly, shall not be the automatic consequence of the recourse to the social assistance system and secondly, may in no case be adopted against Union citizens who are workers or self- employed persons and their family members, Art. 14(4)(a) CRD. This holds also true for job-seekers, if they can proof that they are continuing to search for work and that there exists a genuine chance of being employed, Art. 14(4)(b) CRD.

\section{Retention of the status of worker or self-employed person}

The CRD also provides for the situation where economic activity of the primary Union citizen changes, Art. 7(3) CRD, but the status is retained. The legal consequence of retention of the status is that further periods counting towards the permanent right of residence may be accumulated.

${ }^{131}$ See also Case C-36/75, Rutili, 28 October 1975, para 53. 
The provision recognises four different situations. ${ }^{132}$ If a worker or a self-employed person ceases to be a worker or a self-employed person, the status of worker or self-employed person can be retained under certain conditions. This applies if the Union citizen is temporarily out of work as the consequence of an illness or accident (a). After being employed for more than one year, the right to reside continues if the former worker becomes involuntarily unemployed and is registered as a jobseeker with the relevant employment office, (b). Only if the involuntary unemployment starts within 12 months, even if as a consequence of a fixed term contract of less than 12 months, and given the registration as job-seeker, the status as worker only continues for at least six months (c). The status as worker also continues in case the Union citizen embarks on vocational training. This training must be related to the previous employment, unless the unemployment is involuntarily (d). The CJEU has extended the right to retain the status to prisoners who were employed before their imprisonment. The fact that these persons are not available for employment during imprisonment does not generally preclude them from continuing to be duly registered as belonging to the labour force, provided that the person actually finds another job within reasonable time, after being released ${ }^{133} \mathrm{~A}$ further case where the retention of the status of worker was safeguarded concerned the situation of a pregnant woman. The CJEU held that 'it does not follow from either Art. 7 of Directive 2004/38, considered as a whole, or from the other provisions of that directive, that, in such circumstances, a citizen of the Union who does not fulfil the conditions laid down in that Article is, therefore, systematically deprived of the status of 'worker', within the meaning of Art. 45 TFEU'. ${ }^{134}$ The CJEU stated that the list in Art. 7(3) is, contrary to the interpretation given to it by the UK government, not exhaustive, and the woman who gives up work and work search temporarily in the late stages of pregnancy retains her status as worker under Art. 45 and the particular protection of maternity in EU law, ${ }^{135}$ and 'provided she returns to work or finds another job within a reasonable period after the birth of her child'. ${ }^{136}$

\section{Retention of the derived right to reside in case of death or departure of the primary Union citizen}

Generally, the death or departure from the host Member State of the Union citizen does not affect the right to reside of those family members who are also Union citizens themselves and have a permanent right to reside, Art. 12(1) CRD. After three months and up to 5 years, they must themselves have a primary right to reside in accordance with Art. 7(1) CRD.

The situation for TCN family member is different. Before acquiring the right of permanent residence, the person concerned must demonstrate the status as worker or self-employed person, or of being self-sufficient and having comprehensive sickness cover including their family in the host Member State. Alternatively, they must evidence that they are family members of the family, already constituted in the host Member State, of another person who satisfies these criteria, Art. 12(2). Provided that these conditions are fulfilled, the Union citizen's death shall not lead to the loss of the right to residence for those TCN family members who have been residing in the host Member State with the Union citizen at least for one year before the death occurred.

\footnotetext{
${ }^{132}$ C. Barnard, p. 243.

${ }^{133}$ Cases C-482/01 and C-493/01, Orfanopoulos, 29 April 2004, para 50.

${ }^{134}$ Case C-507/12, Jessy Saint Prix, 19 June 2014, para 31.

135 Jessy Saint Prix, note 134, para 45, pointing to Art. 16(3) CRD.

${ }^{136}$ Jessy Saint Prix, note 134, para 47.
} 
It is also important to notice that in any case the remaining family members retain their right of residence exclusively on a personal basis. They cannot confer a right to reside on other family members, who do not satisfy the outlined conditions, but they can accumulate further periods to gain the right of permanent residence, Art. 17 CRD.

A different situation arises if the Union citizen's departure or death leaves a child behind. Irrespective of nationality, these children retain their right to reside. The same holds true regarding the parent who has actual custody of the children, if the child resides in the host Member State and is enrolled at an educational establishment and studies there, until the end of the studies. Art. 12(3) CRD.

\section{Retention of the derived right to reside in case of divorce, annulment of marriage or termination of registered partnership}

The CRD applies the same technique of differentiation between family members who are Union citizens and those who are TCNs, to the situation where the personal bond between the primary Union citizen and the family member is curtailed.

In those cases, the Union citizen family member must themselves prove that they have a primary right to reside in accordance with Art. 7(1) TFEU or that they have already acquired a permanent right to reside.

For TCN family members, the same applies, before they have acquired a permanent right to reside; they must also prove that they are workers, self-employed persons or that they have sufficient resources for themselves and their family members not to become a burden on the social assistance system, Art. 13(2) CRD. In addition, they must also fulfil further criteria, if the right to reside is to be retained. This includes that the marriage or registered partnership has lasted at least for one year in the host Member State and three years in total (a), or the spouse or partner must obtain the legal right of custody for the Union citizen's children (b), or the retention of the right is warranted by particularly difficult circumstances, for instance the TCN spouse or partner being victim of domestic violence during the marriage or partnership (c), or if the spouse or partner has the right to access to a minor child, provided that a court ruled that access must take place in the host Member State (d).

Again, these rights of TCN family members are retained exclusively on a personal basis and entail the right to accumulate periods relevant for the permanent right of residence, Art. 17 CRD.

\section{Restrictions on the right of entry and the right of residence}

The CRD establishes as a general principle that Member States have the right to restrict the freedom of movement and residence on grounds of public policy, public security or public health, Art. 27 CRD.

To that end, the CRD provides guidance on the application of the principle of proportionality. If restrictive measures are taken based on public policy or public security, they must be based on the personal conduct of the individual concerned. The person must represent a genuine, present and sufficiently serious threat affecting one of the fundamental interests of society at present, previous criminal convictions shall not in themselves be sufficient. General prevention is also not an acceptable reason, Art. 27(2) CRD. 
Within three months of the arrival of a person who may represent a threat to public policy or public security, the host Member State has the right to request the Member State of origin and other Member States to provide information concerning any previous police record of the person concerned, art. 27(3) CRD. This does not entail the right for routine investigations of such nature. In the case of an expulsion decision, the Member State who issued the passport or identity card is obliged to allow the person concerned to re-enter its territory. This holds true even if the documents are no longer valid or the nationality of the holder is in dispute, Art. 27(4) CRD.

\section{Expulsion}

The further considerations which must guide the decision on expulsion are staggered in relation to the duration of residence, the age of the person, the health status, family and economic situation, social and cultural integration in the host Member State and the extent of remaining links with the country of origin, Art. 28(1) CRD.

For those Union citizens who have the right of permanent residence, only serious grounds of public policy or public security can be considered. For those Union citizens who have resided in the host Member State for the previous 10 years or a minor, an expulsion decision can only be based on imperative grounds of public security, Art. 28(2) CRD. There restriction does not apply if the expulsion is necessary for the best interests of the child in accordance with the UN Convention on the Rights of the Child, Art. 28(3) CRD.

A restriction of free movement on the grounds of public health is only justifiable within the first three months of arrival of the person concerned, Art. 29(2) CRD. Furthermore, the disease must have an epidemic potential as defined by the relevant instruments of the World Health Organisation and other infectious or contagious parasitic diseases if they are the subject of protection provisions applying to nationals of the host Member States, Art. 29(1) CRD. Member states are entitled to require the person concerned to undergo a medical examination free of charge; however, this may not be required as a routine measure.

Further procedural guarantees apply to the expulsion decision.

The person concerned must be notified in writing to ensure that they comprehend the decision and its implications, Art. 30(1) CRD. They are also entitled to be informed precisely and in full, of the public health policy, public security or public health grounds on which the decision was taken. This right can only be excluded in the interests of State security, Art. 30(2) CRD.

The person concerned must also have access to judicial review, Art. 31 CRD and be informed on the right to appeal, Art. 30(3). Only in substantiated cases of urgency can the allowed time to leave the territory be less than one month.

In cases where the application for review of the decision is accompanied by an application for interim measures, a removal from the territory may not take place. However, exceptions exist.

This suspension cannot be invoked if the expulsion decision is based on a previous judicial decision, or where the person concerned already had access to judicial review, or where the expulsion decision is based on imperative grounds of public security under Art. 28(3) CRD. The review shall comprise the facts of the case and the legality of the decision, Art. 31(3) CRD. 
Member states have the right to exclude the individual from their territory pending the redress procedure, but this does not affect the right of the person to submit the defence in person. This right can only be restricted if the presence of the person may cause serious troubles to public policy or public security or when the appeal itself concerns a denial of entry to the Member State, Art. 31(4) CRD.

After being excluded from the territory of a Member State on grounds of public policy or public security, a person may apply for lifting of the respective order after three years, or earlier, depending on the circumstances. A decision based on the reasons that might justify such a decision must be adopted by the Member State within 6 months, during which no right of entry exists. Art. 32(2) CRD.

\section{PART THREE: POLITICAL RIGHTS}

This Part will focus on how the political rights associated with EU citizenship may be enshrined in Union legislation. It will look at the right to vote and stand as candidate in elections to the European Parliament and in municipal elections (Art. 20(2)(b) and 22 TFEU); diplomatic representation (Art. 20(2)(c) and 23 TFEU) and the rights to citizen's initiative, petition to the European Parliament, application to the European Ombudsman and reply from the Union bodies in the same language (Art. 20(2)(d) and 24 TFEU). The analysis will be broken down in accordance with the two options put forward previously.

Two notes relevant for both options should be made before proceeding: the first on who should be entitled to those political rights and the second on the conditions needed for those rights to be conferred (the how).

As for who should be entitled to the political rights, these should be made available to the current citizens and family members joining them in the future even if yet unborn, as per the Commission Working paper Essential Principles on Citizens' Rights published on May $30^{\text {th }}$. This covers both current Union citizens, as well as those that will acquire the Citizenship rights if not the Citizenship itself via a family relationship in the future. For the Continuity option, a question should be posed, however, if the family relationship should be limited in time or by generations and it is posited that some sort of limit should be considered. For example, it is reasonable to interpret the citizenship right as directly dependent on a current citizen, ie that the right only extends to immediate descendants of a current citizen and not subsequent generations. In addition, those British citizens that acquire the nationality by naturalisation after Brexit should not have conferred on them any of these rights unless they meet the necessary criteria stated above, for example, by marrying a British national who already has the Union Citizenship via one of the modalities mentioned here.

Regarding how those rights are to be conferred, the answer is that every Union citizen acquires those rights immediately upon obtaining the citizenship. Therefore, those rights remain dormant while the individual resides in his/her home country and become active after exercising free movement rights by residing in another Member State, with the exception of the right of diplomatic representation (Art. 23 TFEU) and the right to petition of (Art. 24 TFEU). In consequence, the 
question of how they become active is separate from conferral and there is no reason why UK citizens should be treated differently under either of the options proposed.

\section{A. Continuity of Union Citizenship}

\section{Right to vote and stand for European Parliament and municipal elections (Art 22 TFEU)}

The right to active and passive suffrage associated with citizenship of the Union currently depends on the individual living on a Member State different from his/her own, since the local (or national) suffrage rules apply to him or her if that is not the case. Therefore, in what concerns UK citizens after Brexit, their Union Citizenship rights would only apply if they were residents in a Member State, entailing no change from the current situation. There would be no UK European Parliament constituencies, therefore both the passive and active suffrage rights in what concerns elections for the European Parliament would always require the exercise of the free movement right. Naturally, the same requirement would apply (as it does today) to the suffrage rights in local elections.

As maintaining this right would not require any change from the status quo, monitoring and implementation could be accomplished by the same tools Member States already use today: a mix of identification and registration methods which vary from Member State to Member State. As long as the individual can provide evidence of British citizenship by means required by the Member State, there should be no additional difficulties or costs involved with maintaining this right. The exception might be those citizens that acquired the British nationality via naturalisation post-Brexit without any family member being a Union citizen. ${ }^{137}$

\section{Right to diplomatic and consular representation (Art. 23 TFEU)}

Art. 23 TFEU provides citizens of the Union with the right to diplomatic and consular representation by any Member State when in the territory of a third country in which its home Member State does not have consular representation itself. As mentioned in the introduction to this section, this is a right whose exercise does not depend on an active measure by the Union citizen and becomes active even if he/she has never exercised their free movement rights to live in another Member State. In what concerns the Continuity option, it raises significant questions.

Consular protection as designated in Art. 23 TFEU clearly depends on and assumes a reciprocity at national level: all Member States agree to protect other EU citizen nationals if needed be. Although the right is vested in the individual, the obligations arising from it take place outside the Union and belong to the Member States on a reciprocity basis. There are two ways this right can be interpreted and applied under the Continuity option.

137 Data from the Migration Observatory indicates 118,000 foreign citizens acquired British citizenship in 2015, around 100.000 of those coming from third countries, available at: http://www.migrationobservatory.ox.ac.uk/resources/briefings/naturalisation-as-a-british-citizenconcepts-and-trends/ 
First, as this right is vested in the citizen and is not dependent on the exercise of any other right, then just by reason of the fact it has vested, Member States need to comply with it. Under this approach, diplomatic representation and consular rights would be treated no differently from all other political rights covered in this section. Under the Continuity model that approach is consistent with the perspective that rights have been conferred on the citizens by means of the Union Citizenship and those cannot be taken away due to no fault of the citizen. In consequence, postBrexit the Member States would still be under the obligations imposed by Art. 23 TFEU towards those British citizens that have acquired the Union Citizenship.

Second, the opposite view can also be offered. As this is a right so dependent on State solidarity and reciprocity it can be argued that although it is vested in all Union citizens, its availability and exercise depends on reciprocity and the ability for the countries involved to work closely together. As such, from a practical perspective, this right would always require a specific agreement between the UK and the Member States under the withdrawal process of Art 50 establishing the terms of how such rights may be exercised, probably with reference to the Vienna Convention of 24 April 1963 on Consular Relations (particularly Art. 8). This possibility poses some specific difficulties as either the agreement would refer to current EU legislation ${ }^{138}$ and that would lead to a divergence in rules if those were to be changed in the future or subject to the interpretation of the CJEU, or it would not and would require a mechanism for the parties to agree on subsequent changes.

\section{Citizen's initiative, petition to the European Parliament, application to the European Ombudsman and reply from the Union bodies in the same language (Art. 24 TFEU and Art. 11 TEU)}

Art. 24 TFEU confers four different rights on Union citizens: citizen's initiative, petition to the European Parliament, application to the European Ombudsman and to correspond with the Union's bodies in one of the languages included in Art. 55(1) TEU. Taken together, the maintenance of these rights under the Continuity option does not offer significant difficulties as they would be rolled over from the status quo.

As citizens of the Union, UK nationals benefiting from the Continuity option should be entitled to exercise these rights as they have been so far and in the same way that the nationals from the EU-27 will be exercising them post-Brexit. As such, these rights do not require as a prerequisite the exercise of free movement rights to become active, as we posited above for active and passive suffrage rights.

Having said that, regarding the citizen's initiative there is a specific limitation in Art. 11(4) TEU, as this Art. requires 'nationals of a significant number of Member States' to underwrite it. As the UK will no longer be a Member State of the Union, then the fact some of its citizens underwrote the

138 In addition to Art. 20(2)(c) and 23 TFEU, that includes Council Directive (EU) 2015/637 of 20 April 2015. 
citizen initiative will only count for the individual number of supporters and not for the minimum number of Member States requirement.

\section{B. Associate Citizenship}

Within the option of Associate Union Citizenship, the rights to be conferred will either have to be negotiated within the context of the Withdrawal Agreement under Art. 50 TFEU, perhaps as part of a reciprocal deal. From an operational perspective, this option appears simple and the same time provides a stable legal environment to operate in since it would cover all citizens for the duration of the agreement. It also looks well suited to the model proposed in the Position Paper 'Essential Principles on Citizens' Rights' dated June 12th. It still raises specific challenges such as which jurisdictional body will oversee and enforce the rights that are agreed by the parties and how can the rights of UK citizens be kept up to date and in sync with the legislation of both the Union and the UK as it evolves in the future. However, those are challenges common in complex international treaties and are not insurmountable by creating appropriate tools and discussion fora. There appear to be no reasons why the political rights cannot be part of the negotiation during the UK's withdrawal process and it is conceivable as well that only some of these rights might be agreed upon by the parties and others should not be included at all, such as the active and passive suffrage for European Parliament elections.

\section{Right to vote and stand for European Parliament and municipal elections (Art 22 TFEU)}

As for the suffrage rights, within the context of a EU/UK agreement, these would have to be negotiated and due consideration given to the fact that EU citizens living in the UK would not be able to vote for the European Parliament elections due to the lack of constituencies in the UK - the same reasoning we have expressed above for the Continuity option. As such, a reciprocal type of agreement would imply suffrage rights to be limited to municipal elections.

\section{Right to diplomatic and consular representation (Art. 23 TFEU)}

As referred to in the previous section, the right to diplomatic and consular representation is tightly connected to the Member States as, after all, it is their diplomatic services which will provide assistance in case of need. This is clearly a right that only makes sense within a reciprocal agreement that would have to be negotiated between the parties during the Withdrawal Agreement.

\section{Citizens' initiative, petition to the European Parliament, application to the European Ombudsman and reply from the Union bodies in the same language (Art. 24 TFEU and Art. 11 TEU)}

Since these rights are connected with the direct relationship between the citizen and EU institutions, these can be offered as part of the Withdrawal Agreement process and do not require reciprocity from the UK, since the country already provides similar rights of petition and application to multiple Ombudsmen in the country. As for the citizen's initiative and language of correspondence they 
appear to be non-contentious even though the UK has not (and is not expected to have) similar arrangements.

\section{PART FOUR: DEVOLUTION (Enshrining citizenship rights in the law of Wales)}

This Part addresses the possible role of devolved government in the UK in delivering, within the UK, the rights currently associated with the status of EU Citizen. EU citizens currently enjoy wide rights within the UK. It is assumed that the establishment of either status would require reciprocity. The granting of rights to UK citizens within the EU-27, by virtue of their Union Citizenship of Associate Union Citizenship would presumably require the continuation or creation of similar rights to be enjoyed by EU citizens within the UK.

The Part demonstrates that a number of rights currently flowing from EU citizenship are delivered by legislation which is within the legislative competence of the National Assembly for Wales (and the other devolved legislatures - the Scottish Parliament and the Northern Ireland Assembly). These rights arise in certain subject areas (health, education, voting rights etc.). The maintenance of access to those rights by EU citizens (as part of reciprocal arrangements permitting UK citizens to continue to have access to similar rights in the continuing EU) would, under current UK constitutional conventions, require the active co-operation of the devolved legislatures and governments. The importance of the contribution of devolved government to such an arrangement should not, however, be over-stated; currently, access to many of the rights in question depends not on the citizenship of the individual but on presence, residence, or ordinary residence of that person within the devolved territory and would therefore not be affected by the UK's exit from the EU;

Sight should also not be lost of the greater importance, in relation to the current rights of EU citizens within the UK, of competences reserved to the UK level, including that relating to social security benefits and, above all, those relating to the control of entry into, and residence in, the UK. The role of devolved government in establishing and maintaining the enjoyment, within the devolved territories, of rights associated with Union Citizenship of Associate Union Citizenship would need to operate subject to the reservation to the UK Parliament of international relations, including relations with the EU and its institutions.

\section{A. The role of devolved government in relation to rights associated with citizenship}

Almost uniquely amongst developed democratic states ${ }^{139}$, the UK has no codified written constitution. Its constitutional law rests, instead, on the principle of Parliamentary Sovereignty. Under this principle Parliament ${ }^{140}$ has unfettered power to make law (by Act of Parliament) applicable to the UK and those other territories over which Parliament exercises jurisdiction ${ }^{141}$.

Executive powers within the UK are vested in the Crown (i.e. the Queen, acting in her constitutional capacity) but are in practice exercised in the name of the Crown by Ministers responsible to Parliament. Except for a small number of inherent "prerogative" powers, the executive powers of

\footnotetext{
${ }^{139}$ New Zealand, whose constitutional tradition closely reflects that of the UK is another ${ }^{140}$ In this sense, the Queen and the two Houses of Parliament (Lords and Commons), acting together ${ }^{141}$ British Overseas Territories - see also Part 2 below.
} 
the Crown arise under Parliamentary legislation, which delegates specific defined powers to Ministers.

By a trilogy of Acts of Parliament enacted in 1998 (the Scotland Act 1998, the Government of Wales Act 1998 and the Northern Ireland Act 1998) the UK Parliament created representative bodies (the Scottish Parliament, the National Assembly for Wales and the Northern Ireland Assembly) to exercise governmental powers in those respective territories. The form taken by this devolution of power differed between the territories in question. In particular, only executive powers, previously exercised by UK Ministers, were delegated to the National Assembly for Wales ("NAW"). But a further reform, the Government of Wales Act 2006, brought the powers of NAW much more closely into line with those of the Scottish Parliament and of the Northern Ireland Assembly.

The pattern of devolved government in each of the three devolved territories is therefore nowadays very similar and also resembles the traditional "Westminster" model which operates at a UK level. There is, in each case, an elected parliamentary body and a local executive which is answerable to it. The parliamentary body has the power to make law in relation to the territory in question on some (but not all) matters. It scrutinises the activities of the executive (the Welsh Government ("WG") in the case of Wales), a body which continues in power only so long as it retains the support ("confidence") of the parliamentary body. The parliamentary body also retains ultimate control over expenditure; the executive's budget is subject to its approval.

The UK's system of devolved government may be described as a "quasi-federal" system in that it differs, in three significant ways, from a true federation.

Fully federal systems are invariably created and maintained as part of a system of government defined by a codified written constitution. Devolution within the UK exists, on the other hand, within the uncodified, unwritten UK constitution which is based on the sovereignty of the UK Parliament. UK devolution is therefore, formally, an exercise in the partial delegation to the devolved legislatures of powers previously exercised exclusively by the UK Parliament.

Secondly (and as a necessary consequence of the fact that devolved government in the UK exists subject to the overarching principle of UK Parliamentary Sovereignty) the UK Parliament retains, constitutionally, the power to make law for all parts of the UK, even in relation to matters on which the devolved legislatures can legislate. This has, however, been subject, since the inception of devolution, to a convention that the UK Parliament will not normally legislate on devolved matters without the consent of the relevant devolved legislature. Under UK law, constitutional conventions cannot themselves be enforced directly by the courts, although the courts recognise their existence and they can have indirect legal effect. ${ }^{142}$ But a recent development is that the convention in question is now (in relation to Scotland and Wales) recognised by statute ${ }^{143}$. However, in $R$ (Miller) $v$ Secretary of State for Exiting the European Union (2017) ${ }^{144}$ the UK Supreme Court suggested that since the relevant legislation only recognised the existence of the rule in question it remained a convention and, as such, cannot be enforced by the courts. Subject to any further consideration of that proposition by the UK Supreme Court, the position is that in principle any legislation of any of

${ }^{142}$ Attorney General v Jonathan Cape Limited [1976] 1 QB 752

${ }^{143}$ See Scotland Act 1998 (as amended by the Scotland Act 2016) section 28(8), Government of Wales Act 2006 section 107(6) (as amended by the Wales Act 2017).

${ }^{144}$ [2017] UKSC 5 
the devolved legislatures can by nullified by legislation made at a UK level on the same matter (although the political price of overriding the wishes of a devolved legislature, in relation to a devolved mater, may be a heavy one).

The third and most important characteristic of UK devolution which qualifies it to be described as only "quasi-federal" is its asymmetric nature. It applies only to the three devolved territories of Scotland, Wales and Northern Ireland. There are currently no corresponding arrangements in relation to the England, the remaining part of the UK, which constitutes $54 \%$ of its land area and is home to $84 \%$ of its population. The UK Parliament continues to be the sole legislature in relation to England and makes law not only in relation to non-devolved matters that apply to the whole of the UK but also, for England, in relation to those matters that have been devolved to Scotland, Wales and Northern Ireland.

\section{B. Devolved Competences}

Differences exist between the distribution of legislative and executive competences in relation to each of the three devolved territories. This reflects the differing historical, cultural, social and legal characteristics of each territory. None, with one exception, is significant in relation to the purpose of this paper.

The exception in question is that of general social security benefits and pensions which are organised in Northern Ireland on the basis of a separate regime controlled by the Northern Ireland Assembly and Executive (when functioning) whereas in the rest of the UK there is a single regime under the jurisdiction of the UK Parliament and Government. The devolution of these matters to Northern Ireland is based, essentially, on historical reasons rather than any considered analysis of the merits of such an arrangement and the desirability of common arrangements throughout the UK has been recognised, pragmatically, by maintaining a high degree of alignment between corresponding provisions relating to Northern Ireland and the rest of the UK. Whilst it is obvious that reciprocal rights to pensions and social security benefits would be an important issue in relation to any scheme for maintaining Union Citizenship rights or creating new Associate Union Citizenship rights, the anomalous Northern Ireland arrangements will not be considered further, given the focus of this discussion on the Welsh position (which corresponds also to that of Scotland).

Although of little relevance to the individual rights on which EU citizenship is currently based, it is worth mentioning, if only to avoid misunderstandings, that the main difference in competences as between the three devolved territories relates to the legal system, courts, the judiciary, criminal justice and policing. Whereas these subjects are generally devolved in relation to Scotland and largely devolved in relation to Northern Ireland (territories which constitute separate legal jurisdictions) the same is not true of Wales. Wales shares a single legal jurisdiction with England and, as a result, the matters in question continue to be subject, in Wales as well as in England, to the legislation of the UK Parliament and executive functions of UK Ministers.

Generally speaking, the distribution of legislative competences between the UK and devolved legislatures is paralleled by the distribution of executive functions. UK Ministers usually exercise powers under UK legislation whilst ministers in devolved governments exercise powers under devolved legislation (or under legislation in devolved fields made at a UK level prior to devolution). Whenever this paper refers to a subject as being "devolved" this should therefore be understood as meaning, in relation to Scotland and Northern Ireland, that legislative competence in relation to that 
subject has not been reserved to the UK Parliament. In relation to Wales, on the other hand, a "devolved" subject currently means a subject in relation to which competence has been conferred on the National Assembly for Wales. Once the Wales Act 2017 comes fully into force this difference, as between Wales and the other devolved territories, in the strict meaning of what is "devolved" will disappear.

Bearing in mind the above qualifications (and the existence of many second-order exceptions) the current broad distribution of competences as between the UK and Welsh levels is set out in Table 1

TABLE 1

\section{DISTRIBUTION OF LEGISLATIVE COMPETENCES (UK / WALES)}

\begin{tabular}{|c|c|c|}
\hline UK & Shared & Wales \\
\hline $\begin{array}{l}\text { - Constitution, civil service, } \\
\text { political parties } \\
\text { - Foreign affairs (including } \\
\text { relations with the EU and its } \\
\text { institutions) } \\
\text { - Nationality, immigration } \\
\text { - Defence } \\
\text { - National security, counter } \\
\text { terrorism } \\
\text { - Single legal jurisdiction of } \\
\text { England and Wales (including } \\
\text { courts and tribunals, other } \\
\text { than tribunals dealing only } \\
\text { with devolved matters) } \\
\text { - Financial and economic } \\
\text { matters (including currency } \\
\text { and taxation, other than } \\
\text { devolved taxes) } \\
\text { - Crime, public order, policing } \\
\text { - Trade and industry (see the } \\
\text { shared competence for } \\
\text { economic development) } \\
\text { - Energy } \\
\text { - Social security, child support, } \\
\text { pensions and compensation } \\
\text { - Regulation of professions } \\
\text { relations } \\
\text { abortion, genetics, medicines }\end{array}$ & $\begin{array}{l}\text { - Elections (UK has } \\
\text { competence in relation to } \\
\text { electoral law generally and } \\
\text { elections to the UK } \\
\text { parliament but competence } \\
\text { is devolved in relation to } \\
\text { municipal elections and } \\
\text { elections to the National } \\
\text { Assembly for Wales) } \\
\text { - Transport (rail, air and sea } \\
\text { transport and the regulation } \\
\text { of vehicle standards is } \\
\text { generally reserved but roads } \\
\text { are generally devolved) } \\
\text { - Economic development } \\
\text { (there are roughly parallel } \\
\text { competences in relation to } \\
\text { the fostering and support of } \\
\text { economic development) } \\
\text { - Culture and sport } \\
\text { - Taxation (devolved taxes } \\
\text { only) }\end{array}$ & $\begin{array}{l}\text { - Agriculture, forestry, } \\
\text { animals, plants and rural } \\
\text { development } \\
\text { - Education and training } \\
\text { - Environment } \\
\text { - Food } \\
\text { - Health and health services } \\
\text { - Housing } \\
\text { - Local government } \\
\text { - National Assembly for } \\
\text { Wales (internal affairs) } \\
\text { - Public administration } \\
\text { (relating to devolved } \\
\text { services) } \\
\text { - Social welfare (but not } \\
\text { including family law or } \\
\text { social security benefits) } \\
\text { - Tourism } \\
\text { - Town and country } \\
\text { planning (other than } \\
\text { projects of UK significance) } \\
\text { - Water and flood defence } \\
\text { - Welsh language }\end{array}$ \\
\hline
\end{tabular}




\section{- Media}

- Justice, including general criminal, civil, family law

- Land (including registration of title to land)

- Equal opportunities

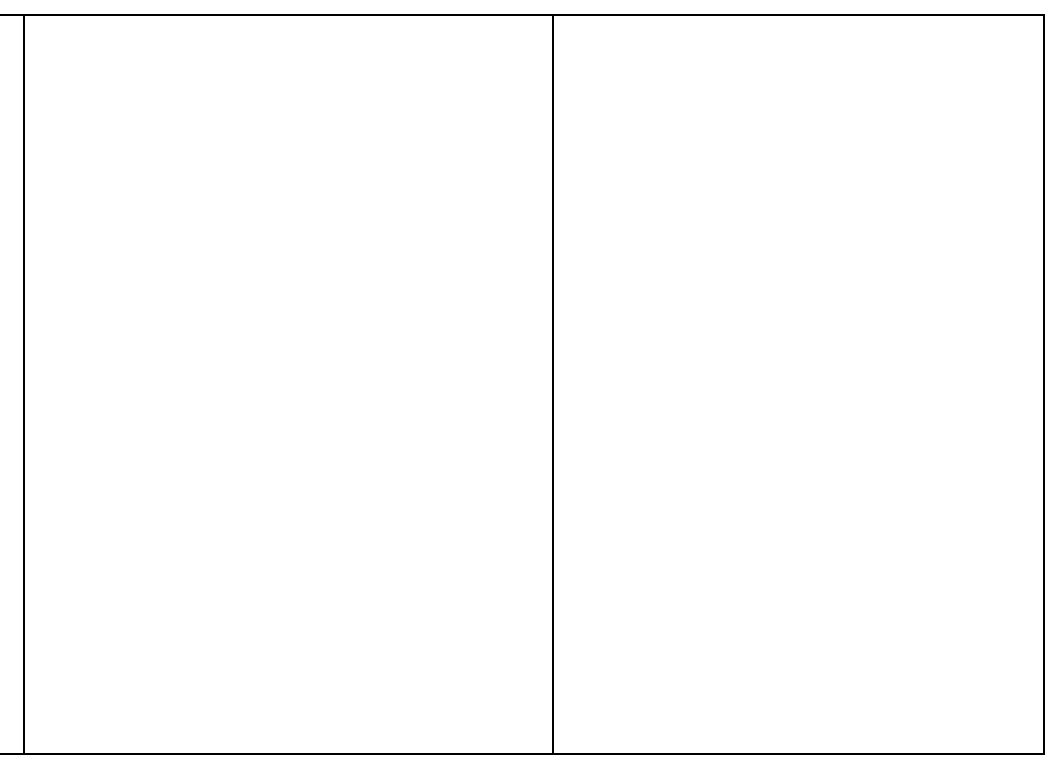

It will be seen from the above analysis of the distribution of legislative competences:

i) that the National Assembly for Wales (in common with other devolved legislatures) has no ability to determine what persons have the right to enter and to reside in the UK (these being matters reserved to the UK Parliament);

ii) that the Assembly, on the other hand, has full competence in relation to a number of areas of government which provide public services to which, in a modern state, individual access is regarded as essential, namely: Health and health services (access to health care); Education and training (access to state education); Housing (access to assistance with housing in case of homelessness); Social welfare (access to care in the case of children or vulnerable adults); Transport (access to public transport on concessionary terms where appropriate);

iii) that the Assembly also has competence in relation to the ability of individuals to vote in elections to bodies which participate in decision-making processes relating to these services; it will (upon coming into full effect of the Wales Act 2017) be able to determine entitlement to vote in Assembly elections and also in elections to local authorities (who are responsible for the delivery of many of the services in question);

iv) a matter reserved to the UK Parliament under the changes made by the Wales Act 2017 is "international relations" which includes "relations with the EU and its institutions". ${ }^{145}$ The possible significance of this reservation is discussed below.

\section{Entitlement to devolved services}

As emanations of the UK state the National Assembly for Wales and Welsh Government are obliged to avoid discriminating against EU citizens, or interfering with the free movement of persons, in the provision of services. ${ }^{146}$

\footnotetext{
${ }^{145}$ Government of Wales Act 2006 (as amended by the Wales Act 2017) Schedule 7A paragraph 10(1) and (2)(b)

${ }^{146}$ TFEU Part 2 and Part 3 Title IV
} 
This obligation is expressly recognised by sections 108(6)(c) and 80(8) of the Government of Wales Act 2006. The former provides that a provision contained in Assembly legislation is outside that body's legislative competence if it is incompatible with EU law. The latter provides that ministers in the Welsh Government have no power to do any act which is incompatible with EU law.

Examples of effect being given to these obligations are as follows:

- $\quad$ Charges for health care services may only be made in respect of persons not ordinarily resident in Great Britain (irrespective of nationality) and then only in cases prescribed in regulations made by Welsh Ministers ${ }^{147}$ but individual EU citizens (and those of EEA states and of Switzerland) are in any event exempt from charges under the National Health Service (Cross-Border Healthcare) Regulations $2013^{148}$ (made, in relation to both England and Wales, under section 2(2) of the European Communities Act 1972 in order to implement Directive 2011/24/EU of the European Parliament and of the Council);

- Compulsory primary and secondary education are provided on the basis of residence and not of citizenship. However, financial support in relation to further and higher education is subject to residence and citizenship criteria, under which EEA and Swiss citizens are treated in the same way as UK citizens ordinarily resident in Wales;

- Local authorities in Wales owe duties in relation to homeless people, based on presence in, or connection with, the area in question and therefore irrespective of citizenship;

- Duties owed by local authorities in Wales in relation to children and vulnerable adults are conditional only on presence within the relevant area and not on citizenship;

- Those over 60 years of age, and disabled persons, are entitled to free concessionary travel on buses in Wales. Entitlement is based on residence rather than citizenship.

\section{The right to vote}

The persons entitled to vote at elections to the National Assembly for Wales are the same as those entitled to vote at local government elections. ${ }^{149}$ These include citizens of the EU. ${ }^{150}$ (Citizens of Ireland and citizens of those EU states which are members of the Commonwealth - Malta and Cyprus - are listed separately; the issue of the rights of Irish and of Commonwealth citizens is discussed below).

Persons who are not UK citizens (and who are not Irish or Commonwealth citizens either) ${ }^{151}$ cannot be elected as Members of the House of Commons. ${ }^{152}$ However, in the case of membership of the National Assembly for Wales membership is also open to EU citizens resident in the UK. ${ }^{153}$ The same is true of membership of local authorities. ${ }^{154}$

\footnotetext{
${ }^{147}$ National Health Service (Wales) Act 2006 section 124(2)(b)

${ }^{148}$ SI 2013 No 2269

${ }^{149}$ Government of Wales Act 2006 section 12(1)(a)

${ }^{150}$ Representation of the People Act 1983 section 2

${ }^{151}$ See the discussion below of the status of Irish and Commonwealth citizens.

${ }^{152}$ Act of Settlement 1701 section 3.

153 Government of Wales Act 2006 section 17(2)

${ }^{154}$ Local Government Act 1972 section 79(1)
} 
The provisions of the Wales Act 2017, when fully in force, will enable the Assembly to modify, by legislation, section 17 of the Government of Wales Act $2006^{155}$ (for example by retaining the ability of EU citizens to be elected as Assembly Members. The Assembly will also be able to legislate in relation to elections to and membership of local authorities, including the entitlement of EU citizens to participate in elections to local authorities (and hence to the Assembly) and the ability of EU citizens to be members of local authorities.

\section{E. Reservation of "foreign affairs"}

Any provision in Assembly legislation that "relates to a reserved matter" is, subject to one exception, outside the Assembly's legislative competence. The exception is that ancillary (e.g. incidental or consequential) provision relating to reserved matters is permitted provided it has no greater effect on those matters than is necessary to give practical effect to a provision which does not relate to reserved matters. ${ }^{156}$

Preservation of existing entitlements of EU citizens to devolved services would not give rise to any issues of legislative competence. Indeed, the convention requiring the UK Government to obtain the consent of the Assembly to UK legislation relating to devolved matters would, if respected, mean that such entitlements could not be withdrawn without the Assembly's consent.

Introduction of new entitlements for EU citizens (or their restoration if they had been withdrawn by UK legislation) would similarly pose no difficulty in itself. The same would be the case if it were required pursuant to an international obligation of the UK (e.g. a treaty establishing mutual entitlements as part of a scheme of continuing or associate EU citizenship). ${ }^{157}$ But were there to be no such obligation the reservation of "relations with the EU and its institutions" means that formal reciprocity with the EU or a role for EU institutions (including the Court of Justice of the European Union) in enforcing the relevant rights associated with Union Citizenship of Associate Union Citizenship could not be achieved at a Welsh (or other devolved) level but only at a UK level.

155 Government of Wales Act 2006 (as amended by the Wales Act 2017) Schedule 7B paragraph $7(2)(a)(v)$

${ }^{156}$ See Government of Wales Act 2006 (as amended by the Wales Act 2017) Schedule 7B paragraph 2

${ }^{157}$ See Government of Wales Act 2006 (as amended by the Wales Act 2017) Schedule 7A paragraph $10(2)(3)(a)$ 